\title{
Formal [8+3]-Annulation between Azaoxyallyl Cations and Tropones
}

\author{
Guillaume Force ${ }^{a}$ \\ Amélie Pérot ${ }^{\mathrm{b}}$ \\ Régis Guillot ${ }^{\mathrm{a}}$ \\ Vincent Gandon*a,b (i) \\ David Leboeuf*a ${ }^{*}$ \\ a Institut de Chimie Moléculaire et des Matériaux d’Orsay (ICMMO), \\ CNRS UMR 8182, Université Paris-Sud, Université Paris-Saclay, \\ Bâtiment 420, 91405 Orsay cedex, France \\ vincent.gandon@u-psud.fr \\ david.leboeuf@u-psud.fr \\ b Laboratoire de Chimie Moléculaire (LCM), CNRS UMR 9168, Ecole \\ Polytechnique, Institut Polytechnique de Paris, route de Saclay, \\ 91128 Palaiseau cedex, France
}

Published as part of the Bürgenstock Special Section 2019

Future Stars in Organic Chemistry

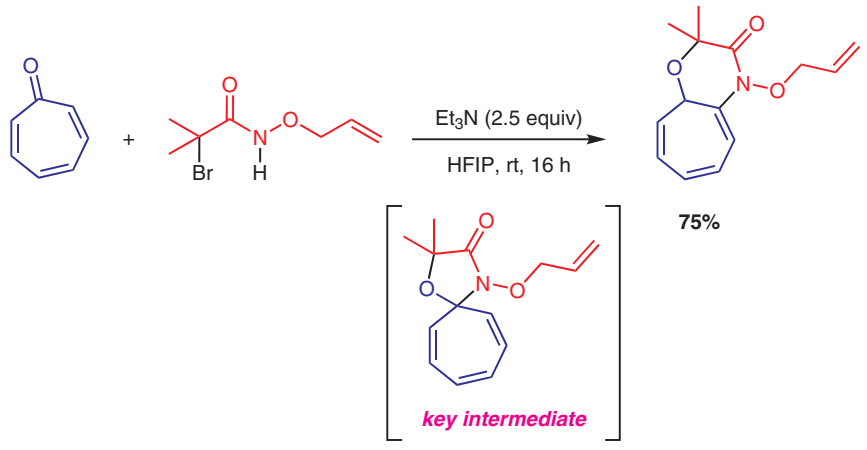

4-oxazolidinones with the alkene moiety remaining intact (Scheme 1a). ${ }^{4 d}$ On the other hand, Fernandez and Sierra reported a tin(IV)-catalyzed [8+3]-cycloaddition between tropones and donor-acceptor cyclopropanes through a mechanism involving a stepwise sequence (Scheme $1 \mathrm{~b}){ }^{2 e}$ Thus, we envisioned that a reaction between tropone and an azaoxyallyl cation would lead to the corresponding 4-oxazolidinone $\mathbf{3}$ and a subsequent [1,2]-shift could provide either $\mathbf{4}$ and/or 4' as products (Scheme 1c). Herein, we report our findings on this transformation along with DFT computations to gain insight into its mechanism.

In our initial studies, we investigated the reactivity of tropone (1) towards $\alpha$-haloamide $\mathbf{2 a}$ in hexafluoroisopropanol (HFIP) at a concentration of $0.2 \mathrm{M}$ (Table 1). Indeed, because of its intrinsic properties such as hydrogen-donor ability combined with a high dielectric constant, ${ }^{5}$ HFIP represents a solvent of choice to stabilize azaoxyallyl cations. As mentioned in the introduction, the formation of azaoxyallyl cations can be easily achieved in the presence of a base, prompting us to screen several common organic and inorganic bases as promoters (Table 1, entries $1-8$ ). We were pleased to find that triethylamine could afford the desired products $4 \mathbf{a}$ and $\mathbf{4}^{\prime} \mathbf{a}$ in $60 \%$ and $8 \%$ yield, respectively, within 3 hours (entry 4). Interestingly, the spiro compound 3a was also detected as a minor product (5\%). The structure of the major product 4a was corroborated by X-ray crystallography (Figure 1 ). Importantly, the reaction had to be carried out in the presence of 2 equivalents of $\mathbf{2 a}$, as the yield of $\mathbf{4 a}$ sharply dropped to $39 \%$ with only 1 equivalent because of a competitive hydrolysis of the $\alpha$-haloamide. It is noteworthy that the concentration of the reaction is a critical factor for its success as decreasing or increasing it derailed the transformation (entries 9,10), essentially leading to the decomposition of the substrates. The influence of drying agents 

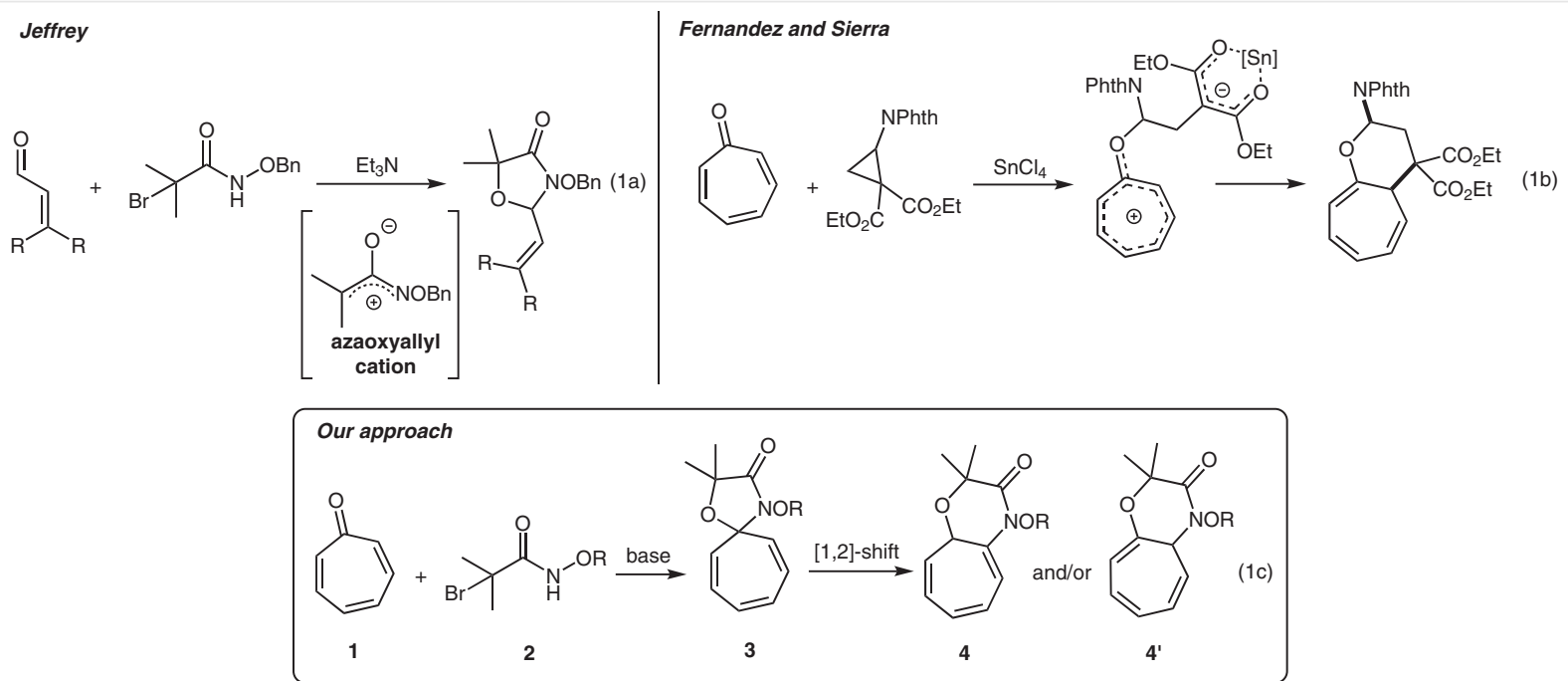

Scheme 1 [8+3] Annulation between tropone and azaoxyallyl cation

Table 1 Reaction Optimization for the Reaction between Tropone (1) and $\alpha$-Haloamide $2 a^{a}$<smiles></smiles>
$\sum_{\mathrm{O}}^{\mathrm{Br}} \downarrow_{\mathrm{NHOBn}} \frac{\text { base (2.5 equiv) }}{\mathrm{HFIP}}$

$2 a$

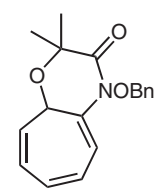

$4 a$

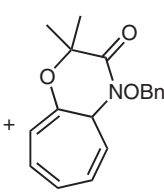

4'a

\begin{tabular}{cllccc}
\hline Entry & Base & Temp $\left({ }^{\circ} \mathrm{C}\right)$ & Time (h) & Yield 4a (\%) & Yield 4'a (\%) \\
\hline 1 & $\mathrm{~K}_{2} \mathrm{CO}_{3}$ & 20 & 3 & 33 & 4 \\
2 & $\mathrm{Na}_{2} \mathrm{CO}_{3}$ & 20 & 3 & 53 & 10 \\
3 & $\mathrm{Cs}_{2} \mathrm{CO}_{3}$ & 20 & 3 & 40 & 7 \\
4 & $\mathrm{Et}_{3} \mathrm{~N}$ & 20 & 3 & 60 & 8 \\
$5^{\mathrm{b}}$ & $\mathrm{Et}_{3} \mathrm{~N}$ & 20 & 3 & 39 & 4 \\
6 & $\mathrm{DABCO}_{6}$ & 20 & 3 & 16 & 2 \\
7 & $\mathrm{DIPEA}^{\prime}$ & 20 & 3 & 44 & 8 \\
8 & $\mathrm{DBU}^{\mathrm{c}}$ & 20 & 3 & 50 & 7 \\
$10^{\mathrm{d}}$ & $\mathrm{Et}_{3} \mathrm{~N}$ & 20 & 3 & 13 & 11 \\
$11^{\mathrm{e}}$ & $\mathrm{Et}_{3} \mathrm{~N}$ & 20 & 3 & 28 & 2 \\
$12^{\mathrm{f}}$ & $\mathrm{Et}_{3} \mathrm{~N}$ & 20 & 3 & 45 & 4 \\
13 & $\mathrm{Et}_{3} \mathrm{~N}$ & 20 & 3 & 59 & 7 \\
14 & $\mathrm{Et}_{3} \mathrm{~N}$ & $\mathbf{2 0}$ & $\mathbf{1 6}$ & $\mathbf{7 1}$ & $\mathbf{9}$ \\
\hline
\end{tabular}

a Reaction conditions: tropone ( 1 ; 1 equiv), $\alpha$-haloamide 2 a (2 equiv), and base ( 2.5 equiv) in HFIP $(0.2 \mathrm{M})$ at the indicated temperature for the indicated time.

${ }^{\mathrm{b}} \alpha$-Haloamide $2 \mathrm{2a}$ ( 1 equiv) and base (1.5 equiv).

c Concentration: $0.4 \mathrm{M}$.

d Concentration: $0.1 \mathrm{M}$.

e In the presence of $\mathrm{MgSO}_{4}$

${ }^{\mathrm{f}}$ In the presence of $4 \AA$ molecular sieves. such as molecular sieves and $\mathrm{MgSO}_{4}$ was also examined but no significant improvement was observed (entries 11, 12). On the other hand, we noticed that the yields could be slightly improved by conducting the reaction for a longer reaction time so that the complete disappearance of the spiro compound was observed (entry 13). As a final point, it is important to emphasize that the ratio between $\mathbf{4 a}$ and 4'a was identical before and after purification by flash column chromatography.

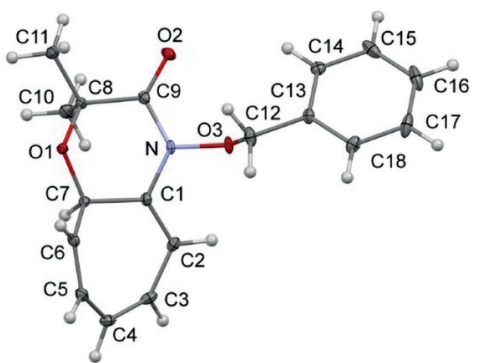

Figure 1 ORTEP drawing of compound 4a. Thermal ellipsoids are shown at $30 \%$ probability level.

Under the optimal reaction conditions, we sought to explore the scope of the reaction, notably the reactivity of tropone (1) with a series of $\alpha$-haloamides (Table 2). Replacing the benzyl substituent by a methyl, tert-butyl, or allyl group did not affect the transformation, providing the targeted products in good yields and selectivities (Table 2, entries 14). Nevertheless, in the latter case, the reaction afforded 4d in $75 \%$ yield with a complete control of the selectivity. To our delight, in the case of $\mathbf{2} \mathbf{b}$, we succeeded to obtain X-ray characterizations of both $\mathbf{4} \mathbf{b}$ and $\mathbf{4} \mathbf{b}$, confirming unambiguously the structure of the minor compound $\mathbf{4}^{\prime} \mathbf{b}$. Surprisingly, with a phenyl substitution, the other isomer 4'e was 
isolated as a sole product in $47 \%$ yield (entry 5 ). On the other hand, in the case of a cyclohexyl tether, the reaction occurred at a slower rate, delivering 4-oxazolidinone $\mathbf{3 f}$ as a major product (64\%) after 3 hours (entry 6). By increasing the reaction time $(36 \mathrm{~h})$, we succeeded to observe the almost complete transformation of $\mathbf{3 f}$ into compounds $\mathbf{4 f}$ and 4'f. While the overall yield is excellent, the selectivity remained not satisfying (entry 7). During our investigations, we also evaluated the reactivity of $\alpha$-haloamide $\mathbf{2 g}$, bearing chlorine substituents, which gave exclusively the spiro compound $\mathbf{3 g}$ in $48 \%$ yield without any further transforma- tion (entry 8). We hypothesized that the electron-withdrawing nature of the substituents precluded any $[1,2]-$ shift and, thus, the reaction was shut down at the first step. In addition, the reaction was also compatible with a secondary bromide such as $\mathbf{2 h}$ to generate the corresponding diastereoisomers $\mathbf{4 h}$, whose configurations were ascertained by NOESY analysis (see the Supporting Information for details), in $32 \%$ and $12 \%$ yield, respectively (entry 9 ). However, in the case of $\mathbf{2} \mathbf{i}$, no reaction occurred, as the azaoxyallyl cation formed might be less electrophilic to trigger the transformation (entry 10).

Table 2 Scope of $\alpha$-Haloamides $\mathbf{2 a}$-i with Tropone (1)
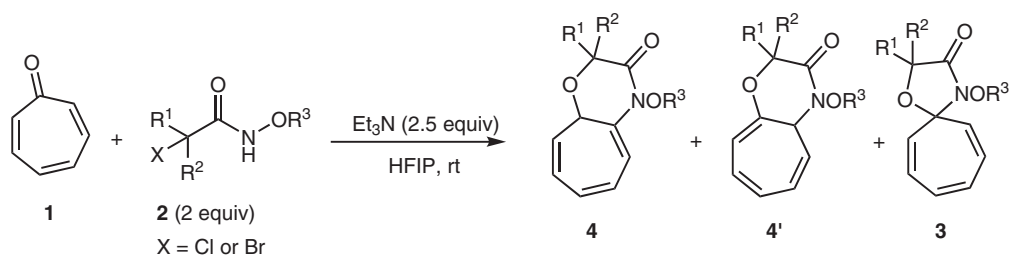

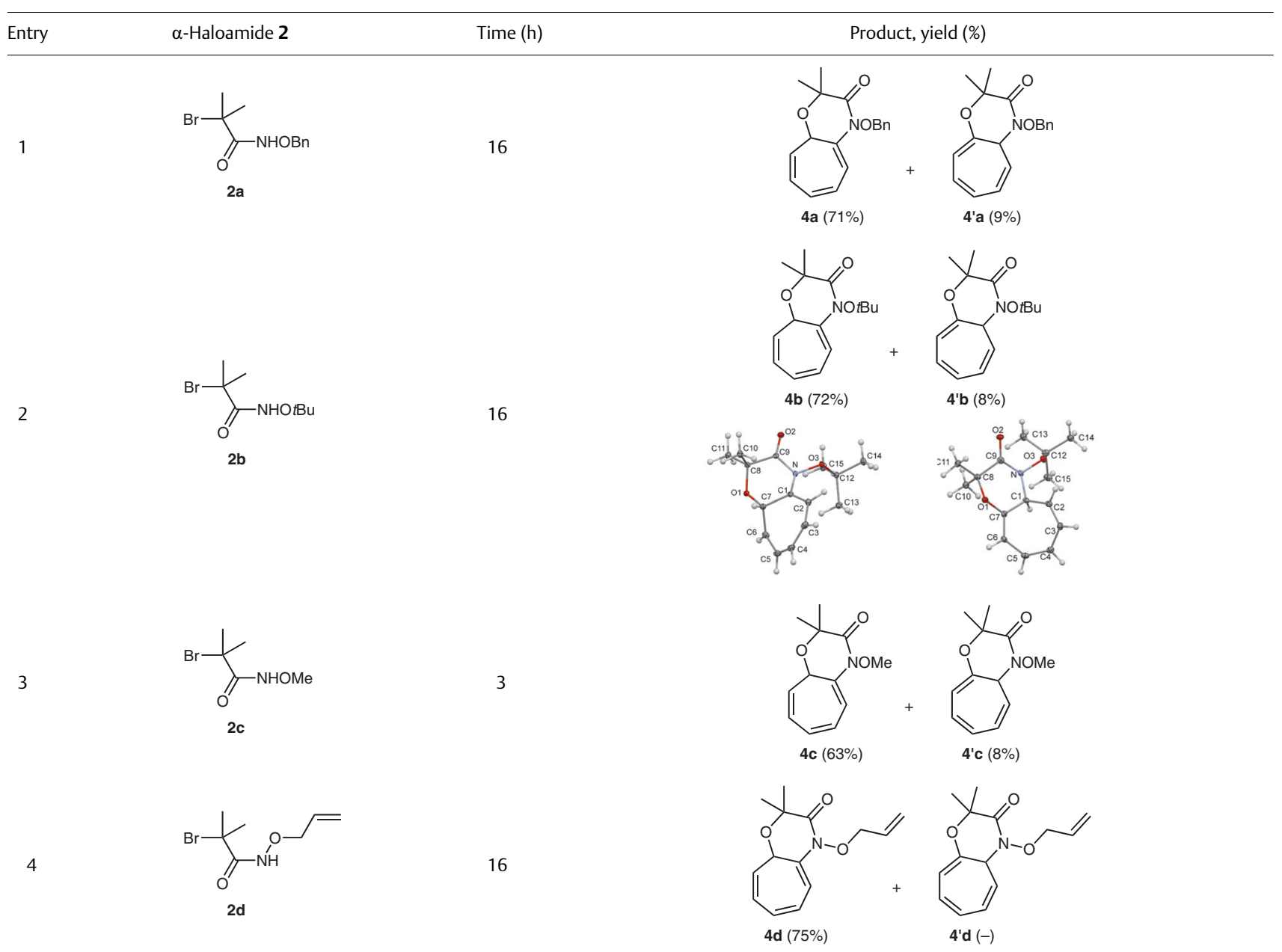


Table 2 (continued)

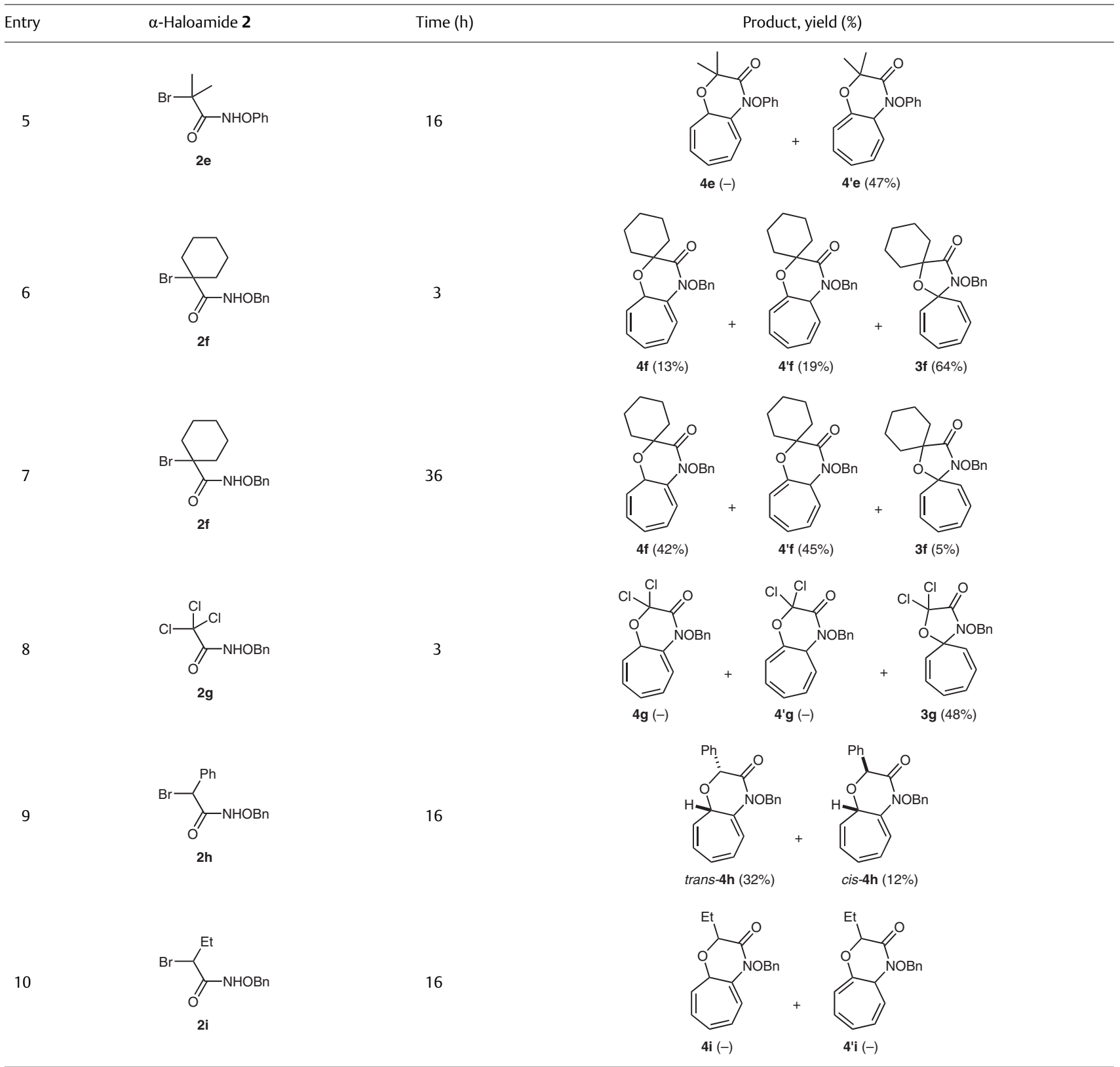

${ }^{a}$ ORTEP drawings of compounds $\mathbf{4} \mathbf{b}$ and $\mathbf{4} \mathbf{\prime} \mathbf{b}$. Thermal ellipsoids are shown at $30 \%$ probability level.

Gratifyingly, the reaction is not only limited to the simple tropone but could also be applied to 2-phenyltropone (5) (Scheme 2). As an example, in the case of $\alpha$-haloamide $\mathbf{2 e}$, the reaction provided compound $\mathbf{6 e}$ in $56 \%$ yield. Its structure was confirmed by X-ray crystallography (Scheme 2 ). On the other hand, the reaction proved to be less selective with $\alpha$-haloamide $\mathbf{2 a}$ as two products $\mathbf{6 a}$ and $\mathbf{6}$ 'a $(\mathrm{X}$-ray crystal structure, Scheme 2 ) were isolated in $56 \%$ and $12 \%$ yield, respectively. Disappointingly, we only observed the decomposition of the tropone derivative when the reaction was conducted in the presence of tropolone and 2-methoxytropone.

Regarding the practical utility of this transformation (Scheme 3), we succeeded to remove selectively the benzyloxy group on the nitrogen to obtain the corresponding free amide $\mathbf{7}$ in $89 \%$ yield by using $\mathrm{Mo}(\mathrm{CO})_{6}$ as a promoter. Two of the three double bonds were reduced with $\mathrm{H}_{2}$ and $\mathrm{Pd} / \mathrm{C}$ in 


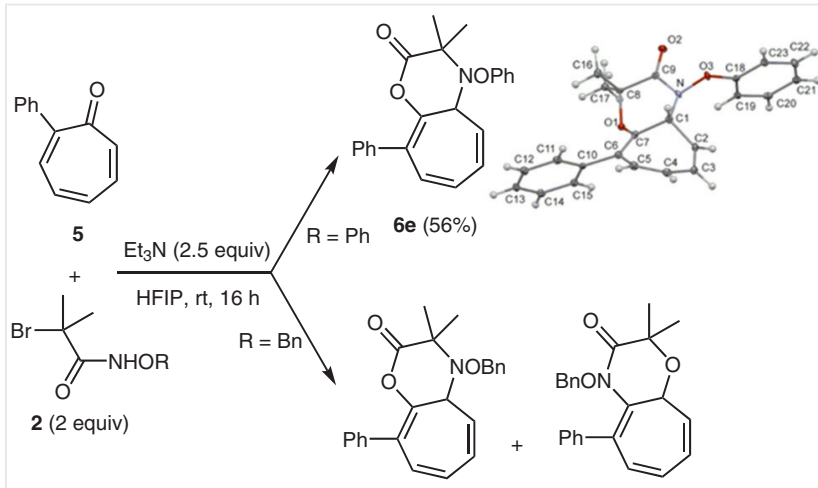

6a (56\%)

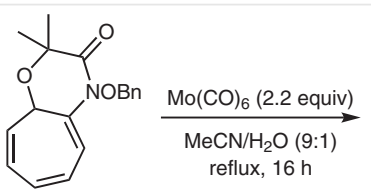

$4 a$<smiles>CCCCN1C(=O)C(C)(C)OC2C=CC=CC=C21</smiles>

4b $\underset{\text { EtOAc, } \mathrm{rt}, 3 \mathrm{~h}}{\stackrel{\mathrm{Pd} / \mathrm{C}(10 \% \mathrm{w} / \mathrm{w})}{\longrightarrow}}$<smiles>CC1(C)OC2C=CC=CC=C2NC1=O</smiles>

7 (89\%)<smiles>CCCCN1C(=O)C(C)(C)OC2CCCCC=C21</smiles>

8 (84\%)

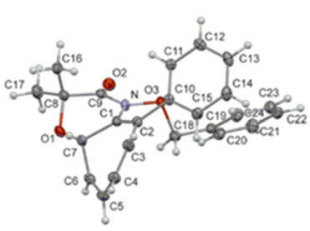

Scheme 2 Influence of tropone substitution on the reactivity. ORTEP drawings of compounds $\mathbf{6 e}$ and $\mathbf{6}^{\prime} \mathbf{a}$. Thermal ellipsoids are shown at $30 \%$ probability level.

ethyl acetate to give $\mathbf{8}$ with the enamide functionality remaining intact. Additionally, the reaction could be performed on a $5.7 \mathrm{mmol}$ scale to produce $1.08 \mathrm{~g}$ of compound 4d without any drop in yield (77\%).

To rationalize the observed selectivity, DFT computations were carried out using the Gaussian 09 software package (see the Supporting Information for details). Minima

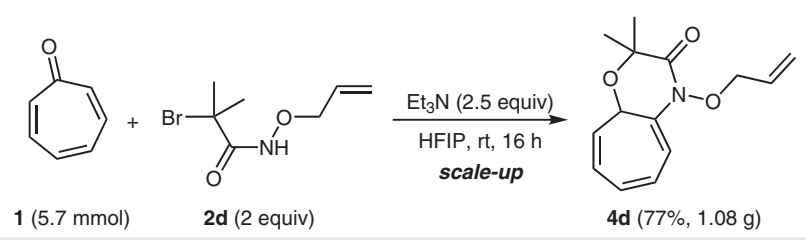

Scheme 3 Post-modifications and scale-up

and transition states were optimized using the M06-2X functional ${ }^{6}$ and the $6-311 \mathrm{G}(\mathrm{d}, \mathrm{p})$ basis set, ${ }^{7}$ as implemented in Gaussian. Solvent correction was obtained using the SMD model $^{8}$ with the parameters of 2-propanol, adjusting the $\varepsilon$ value to $16.7 .^{9}$ The values presented are $\Delta G_{298}$ in $\mathrm{kcal} / \mathrm{mol}$. The first set of computations was carried out with tropone A and the benzyl-substituted 'azaoxyallyl' intermediate B which, in agreement with previous computational studies, converged as a 3-membered ring (Scheme 4). ${ }^{4 \mathrm{k}}$ The capture

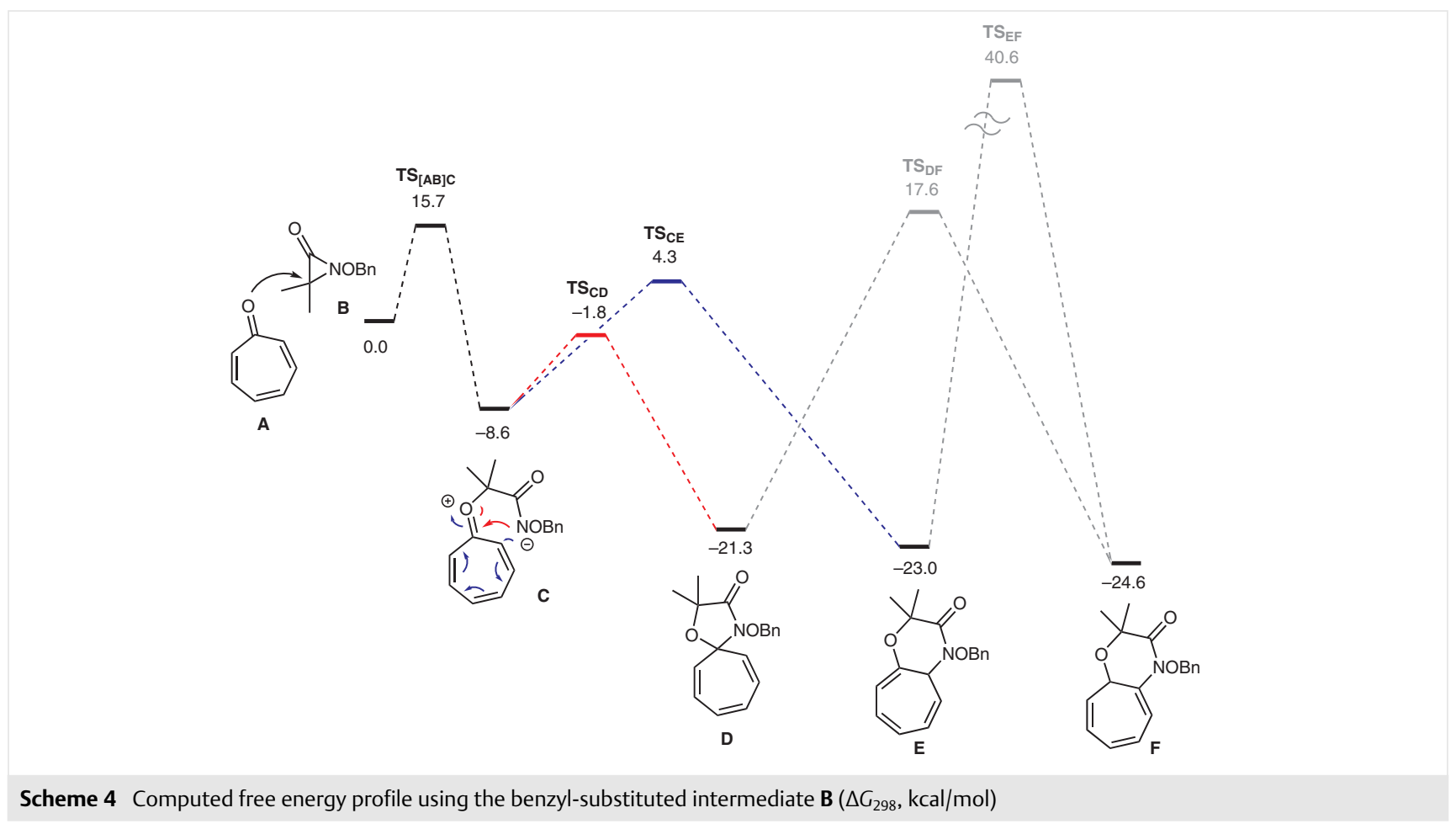


of intermediate $\mathbf{B}$ by $\mathbf{A}$ was modeled though $\mathbf{T S}_{[\mathbf{A B}] \mathbf{C}}$, lying $15.7 \mathrm{kcal} / \mathrm{mol}$ above the reactants. It leads to the zwitterionic species $\mathbf{C}$, located $8.6 \mathrm{kcal} / \mathrm{mol}$ below A and B. Attack of the negatively charged nitrogen atom to the carboxonium center (red pathway, $\mathbf{T S}_{\mathbf{C D}}$ ) leads to the spiro intermediate $\mathbf{D}$, which was observed experimentally as a trace component of the mixture. Another possibility is the conjugate 1,8 -addition (blue pathway, $\mathbf{T S}_{\mathbf{C E}}$ ) to give $\mathbf{E}$. This compound was also experimentally observed as a minor product. The formation of the spiro compound $\mathbf{D}$ is clearly kinetically favored over that of $\mathbf{E}$ ( $-1.8 \mathrm{vs} 4.3 \mathrm{kcal} / \mathrm{mol}$ ). Due to its symmetry-forbidden nature, it was not possible to locate a $[1,7]$-sigmatropic nitrogen shift transition state connecting D to E. On the other hand, the symmetry forbidden [1,7]sigmatropic oxygen shift transition state could be found, but the transformation of $\mathbf{D}$ into $\mathbf{F}$ seems unlikely since the corresponding activation free energy is $38.9 \mathrm{kcal} / \mathrm{mol}(21.3$ +17.6 ). Compound $\mathbf{F}$ is the most stable of the three observed products $\mathbf{D}, \mathbf{E}, \mathbf{F}$ and is a tautomeric form of $\mathbf{E}$. The direct conversion of $\mathbf{E}$ into $\mathbf{F}$ can be modeled, but as it is also a symmetry forbidden shift, the corresponding transition state is not accessible $\left(\mathbf{T S}_{\mathrm{EF}} 40.6 \mathrm{kcal} / \mathrm{mol}\right)$. Thus, similarly to the keto-enol equilibrium, which cannot be an intramolecular process and cannot be computed, the isomerization of $\mathbf{E}$ into $\mathbf{F}$ would require an unknown proton shuttle. Since the isomerization of isolated $\mathbf{E}$ into $\mathbf{F}$ is relatively longer than the reaction time, ${ }^{10}$ we can infer that another way should be possible between $\mathbf{D}$ and $\mathbf{F}$, that is, something not direct as $\mathbf{T S} \mathbf{S}_{\mathbf{D F}}$ and not through $\mathbf{E}$.

A serious lead was obtained after protonating heterocycles $\mathbf{D}, \mathbf{E}$, and $\mathbf{F}$ at the oxygen atom. While $\mathbf{E}$ and $\mathbf{F}$ remained cyclic, the spiro intermediate $\mathbf{D}$ opened to form the corresponding tropylium $\mathbf{G}$ (Scheme $5 \mathrm{a}$ ). It was not possible to form a six-membered ring from $\mathbf{G}$, but removal of a proton and optimization led to $\mathbf{F}$ spontaneously. This suggests that proton-exchanges can directly connect $\mathbf{D}$ to the major product $\mathbf{F}$ in a stepwise fashion. This raises the question of the proton source, the most obvious one being HFIP itself. A single HFIP molecule cannot do this job, as shown by the very large free energy of $37.4 \mathrm{kcal} / \mathrm{mol}$ (Scheme $5 \mathrm{~b}$ ). However, it is known that the acidity of alcohols comes from the formation of H-bonded aggregates, a feature that is excep-

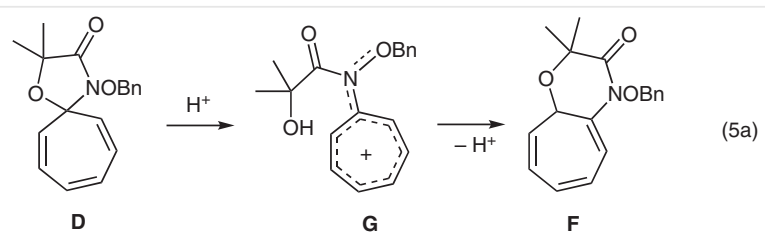

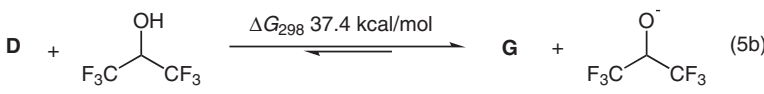

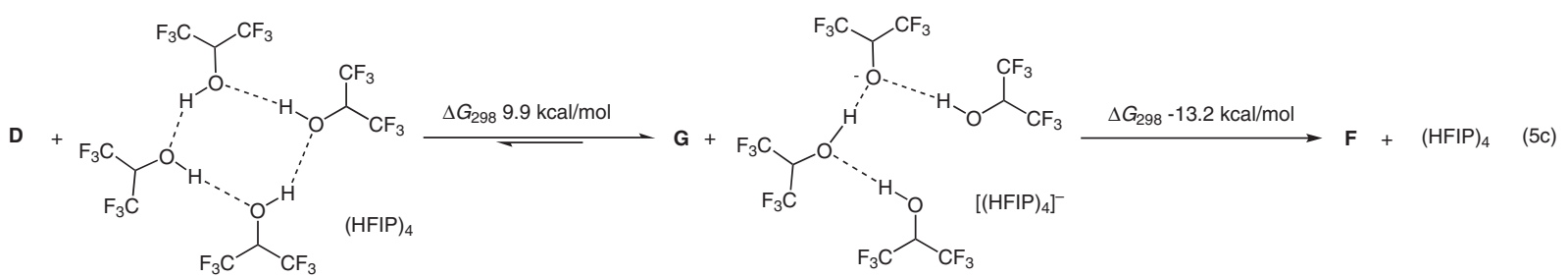

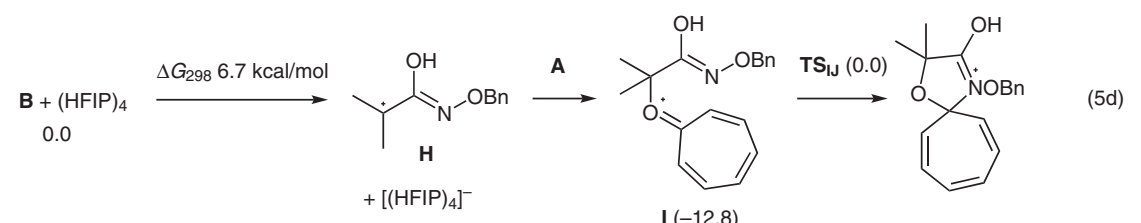<smiles>[TeH2]=C1CCCCC1</smiles><smiles>[Te][As]1CCCC1</smiles><smiles>[R16]N1C2C=CC=CC=C2OC(C)(C)C1O</smiles>

K (-10.0)

Scheme 5 Computed protonation of intermediates $\mathbf{D}$ and $\mathbf{B}$ 
tionally efficient with HFIP. ${ }^{11}$ Taking for instance a tetramer of HFIP, the free energy of the protonation drops to 9.9 $\mathrm{kcal} / \mathrm{mol}$ (Scheme $5 \mathrm{c}$ ). It remains an endergonic reversible process, but the spontaneous formation of $\mathbf{F}$ by simple deprotonation might funnel this reaction. The possible role of HFIP clusters as proton source prompted us to reconsider a cationic mechanism from the beginning (Scheme $5 d$ ). As previously described, cation $\mathbf{H}$, which is the protonated form of $\mathbf{B}$, can be optimized as an azaoxyallyl species. ${ }^{4 \mathrm{~b}}$ Its formation was found exergonic by $6.7 \mathrm{kcal} / \mathrm{mol}$. Manifold efforts failed to locate a transition state between $\mathbf{H}$ and tropone $\mathbf{A}$, and the corresponding adduct I lying at -12.8 $\mathrm{kcal} / \mathrm{mol}$. If formed, I can lead to the protonated spiro compound $\mathbf{J}$, but the corresponding transition state, located at $0.0 \mathrm{kcal} / \mathrm{mol}$, would be $1.8 \mathrm{kcal} / \mathrm{mol}$ higher on the energy surface than $\mathbf{T S}_{\mathbf{C D}}$ and the reaction would be endergonic by $4.5 \mathrm{kcal} / \mathrm{mol}$ (from -12.8 to $-8.3 \mathrm{kcal} / \mathrm{mol}$ ). Of note, the open compound I is also more stable than $\mathbf{K}$, which is the protonated of $\mathbf{E}$. Both can be connected via $\mathbf{T S}_{\mathrm{IK}}$, lying at 4.2 $\mathrm{kcal} / \mathrm{mol}$.

The case of the phenyl-substituted intermediate $\mathbf{B}^{\prime}$ was next studied (Scheme 6 ). The main difference was the absence of the previous zwitterionic intermediate $\mathbf{C}$ because of a direct collapse of the reactants $\mathbf{A}$ and $\mathbf{B}^{\prime}$ to the spiro compound $\mathbf{D}^{\prime}$. From there, the rest of the energy profile is similar to the one computed in the benzyl series.

The formation of $\mathbf{F}^{\prime}$, unobserved experimentally, could yet have happened as explained above, by protonation of $\mathbf{D}^{\prime}$, which again promotes its spontaneous opening into $\mathbf{G}^{\prime}$, and spontaneous ring closure upon deprotonation (Scheme 7a).

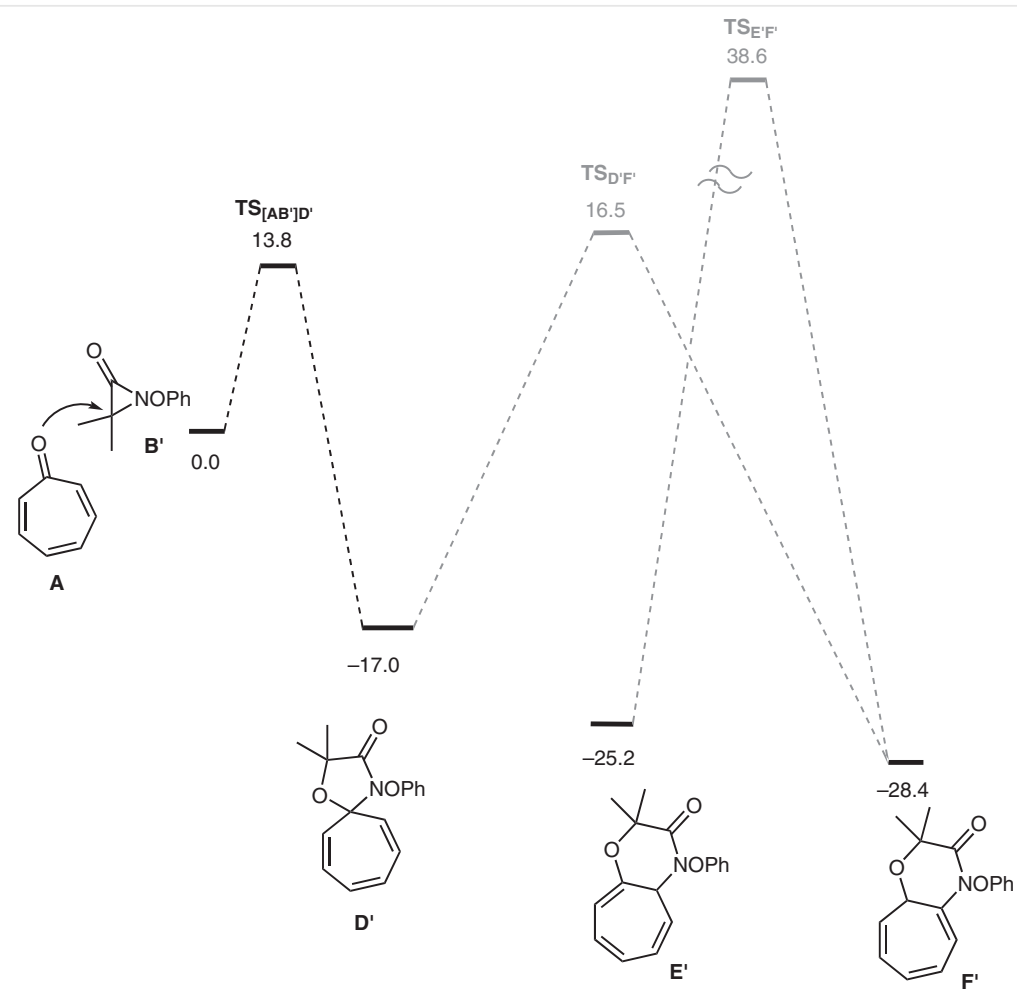

Scheme 6 Computed free energy profile using the phenyl-substituted intermediate $\mathbf{B}^{\prime}\left(\Delta \mathrm{G}_{298}, \mathrm{kcal} / \mathrm{mol}\right)$

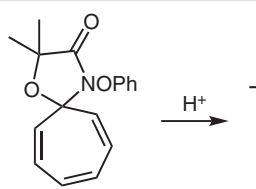

D'

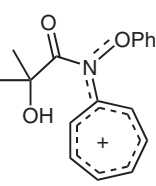

G'

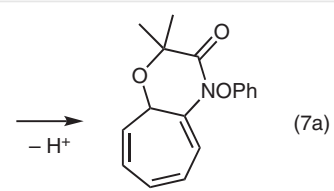

$F^{\prime}$

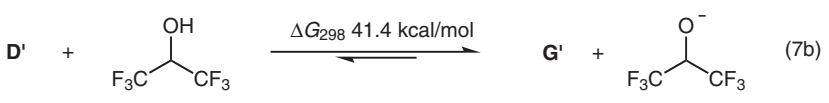

$\mathbf{D}^{\prime}+(\mathrm{HFIP})_{4} \stackrel{\Delta G_{298} 13.9 \mathrm{kcal} / \mathrm{mol}}{\longrightarrow} \mathrm{G}^{\prime}+\left[(\mathrm{HFIP})_{4}\right]^{-} \stackrel{\Delta G_{298}-25.3 \mathrm{kcal} / \mathrm{mol}}{\longrightarrow} \mathrm{F}^{\prime}+(\mathrm{HFIP})_{4}$ (7c)

Scheme 7 Computed protonation of the spiro intermediate $\mathbf{D}^{\prime}$ and deprotonation of $\mathbf{G}^{\prime}$ 
This time though, the formation of $\mathbf{G}^{\prime}$ requires a higher free energy (13.9 vs $9.9 \mathrm{kcal} / \mathrm{mol}$, Scheme $7 \mathrm{c}$ ). This reflects the lower ability of the NOPh group to stabilize the tropylium ion compared to the more basic NOBn group.

Without knowing the exact nature of the proton donor, only trends can be derived from the above calculations. One might propose that each of these reactions circulate through a spiro intermediate, which isomerizes into F-type products in a stepwise fashion by protonation/deprotonation when starting from the most basic substrates. With less basic substrates, the spiro intermediate will rather transform in a stepwise fashion into E-type products (Scheme 8). The way the substitution pattern at $\mathbf{A}$ or $\mathbf{B}$ influences these two pathways seems to obey a subtle balance between steric and electronic effects and is difficult to fully rationalize.<smiles></smiles>

A

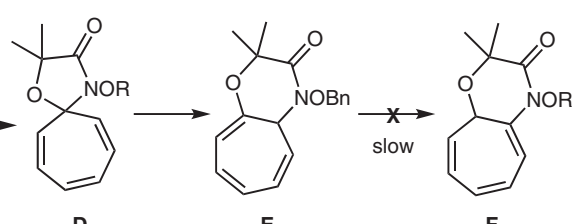

D

E

$\mathbf{F}$ $\mathrm{H}^{+}\left(\right.$from $[\mathrm{HFIP}]_{n}$ ?)<smiles></smiles>

G

Scheme 8 Plausible mechanism

In conclusion, we have devised a formal [8+3]-annulation between tropones and $\alpha$-haloamides, enabling the access to new bicyclic nitrogen-containing scaffolds in good yields, whose selectivity can be controlled by the substituents of the $\alpha$-haloamides. The reaction proceeds under mild conditions by using readily available starting materials and further enriching the synthetic potential of both tropone derivatives and azaoxyallyl cations. The reaction proceeds through a different pathway than the traditional [8+3]-cycloadditions involving tropones as suggested by DFT computations.

Unless otherwise stated, reactions were carried out in oven-dried flasks. Analytical TLC was carried out using TLC-aluminum sheets with $0.2 \mathrm{~mm}$ of silica gel (Merck GF234) using UV light as the visualizing agent and a solution of phosphomolybdic acid in EtOH as the developing agent. Chromatography purifications were carried out using flash grade silica gel (SDS Chromatogel 60 ACC, 40-60 mm). Organic solutions were concentrated under reduced pressure on a Büchi rota- ry evaporator. NMR spectra were recorded at $298 \mathrm{~K}$ on AM250, AV300, or AV360 MHz Bruker spectrometer. Mass spectra were recorded on MicrOTOFq Bruker spectrometer by electrospray ionization. Melting points were determined using a Reichert melting point apparatus. IR spectra were recorded on a FTIR spectrophotometer (PerkinElmer spectrum one, $\mathrm{NaCl}$ pellets or Bruker Vertex 70 ATR Pike Germanium) and are reported in $\mathrm{cm}^{-1}$.

\section{General Procedure for the Cyclization}

To a solution of tropone ( 1 equiv) and $\alpha$-haloamide ( 2 equiv) in HFIP $(0.2 \mathrm{M})$ was added $\mathrm{Et}_{3} \mathrm{~N}$ (2.5 equiv). The reaction mixture was stirred at $\mathrm{rt}$ for the indicated time. Then, it was quenched with sat. aq $\mathrm{NH}_{4} \mathrm{Cl}$ and extracted with EtOAc $(3 \times 10 \mathrm{~mL})$. The combined organic layers were washed with brine, dried (anhyd $\mathrm{MgSO}_{4}$ ), and filtered. The solvent was removed with rotary evaporation. The crude product was purified by flash column chromatography using gradients of pentane and EtOAc as eluent (Table 2).

4-(Benzyloxy)-2,2-dimethyl-4,9a-dihydrocyclohepta[b][1,4]oxazin-3(2H)-one (4a) and 4-(Benzyloxy)-2,2-dimethyl-4,4a-dihydrocyclohepta[b][1,4]oxazin-3(2H)-one (4'a)

Following the general procedure, starting from tropone $(\mathbf{1} ; 30 \mathrm{mg}$, $0.283 \mathrm{mmol}, 1$ equiv), $\mathrm{N}$-(benzyloxy)-2-bromo-2-methylpropanamide (2a; $146 \mathrm{mg}, 0.566 \mathrm{mmol}, 2$ equiv), and $\mathrm{Et}_{3} \mathrm{~N}(98 \mu \mathrm{L}, 0.707$ mmol, 2.5 equiv $)$ in HFIP $(1.4 \mathrm{~mL})$ for $16 \mathrm{~h}$, the crude product was purified by flash column chromatography (100/0 to 95/5 pentane/EtOAc) to afford products $\mathbf{4 a}$ as an orange solid $(60 \mathrm{mg}, 71 \%)$ and $\mathbf{4}$ 'a as an orange solid ( $8 \mathrm{mg}, 9 \%$ ).

$4 a$

Mp 63-65 ${ }^{\circ} \mathrm{C}$.

IR (ATR): 3032, 2982, 2837, 1714, 1698, 1614, 1531, 1455, 1380, 1226 , $1112,1031,983,860 \mathrm{~cm}^{-1}$.

${ }^{1} \mathrm{H}$ NMR $\left(\mathrm{CDCl}_{3}, 300 \mathrm{MHz}\right): \delta=7.40-7.30$ (m, $\left.5 \mathrm{H}\right), 6.54$ (ddd, $J=16.7$, 11.1, $6.2 \mathrm{~Hz}, 2 \mathrm{H}$ ), 6.18 (ddd, $J=9.7,5.7,1.6 \mathrm{~Hz}, 1 \mathrm{H}$ ), 6.00 (dd, $J=6.7$, $1.3 \mathrm{~Hz}, 1 \mathrm{H}$ ), 5.20 (dd, $J=9.7,3.7 \mathrm{~Hz}, 1 \mathrm{H}), 4.92(\mathrm{~d}, J=9.7 \mathrm{~Hz}, 1 \mathrm{H}), 4.81$ $(\mathrm{d}, J=9.7 \mathrm{~Hz}, 1 \mathrm{H}), 3.85(\mathrm{dt}, J=3.5,1.7 \mathrm{~Hz}, 1 \mathrm{H}), 1.56(\mathrm{~s}, 3 \mathrm{H}), 1.40(\mathrm{~s}, 3$ $\mathrm{H})$.

${ }^{13} \mathrm{C} \mathrm{NMR}\left(\mathrm{CDCl}_{3}, 91 \mathrm{MHz}\right): \delta=168.7,133.9,129.9,129.1,128.9,128.8$, $128.5,127.2,124.2,123.1,100.6,77.4,76.4,70.5,25.0,21.4$.

HRMS $\left(\mathrm{ESI}^{+}\right): m / z\left[\mathrm{M}+\mathrm{H}^{+}\right.$calcd for $\mathrm{C}_{18} \mathrm{H}_{20} \mathrm{NO}_{3}$ : 298.1438; found: 298.1430.

\section{4'a}

Mp 70-72 ${ }^{\circ} \mathrm{C}$.

IR (ATR): 2985, 2840, 1710, 1698, 1635, 1455, 1386, 1226, 1050, 998, $865 \mathrm{~cm}^{-1}$.

${ }^{1} \mathrm{H}$ NMR $\left(\mathrm{CDCl}_{3}, 360 \mathrm{MHz}\right): \delta=7.49-7.42(\mathrm{~m}, 2 \mathrm{H}), 7.39-7.30(\mathrm{~m}, 3 \mathrm{H})$, 6.57-6.42 (m, $2 \mathrm{H}), 6.24-6.19(\mathrm{~m}, 1 \mathrm{H}), 5.79$ (d, J = 6.0 Hz, $1 \mathrm{H}), 5.36$ (dd, $J=9.4,4.7 \mathrm{~Hz}, 1 \mathrm{H}), 5.07$ (s, $2 \mathrm{H}), 3.52$ (d, J = 4.4 Hz, $1 \mathrm{H}), 1.58$ (s, 3 $\mathrm{H}), 1.55(\mathrm{~s}, 3 \mathrm{H})$.

${ }^{13} \mathrm{C}$ NMR $\left(\mathrm{CDCl}_{3}, 101 \mathrm{MHz}\right): \delta=169.4,140.2,134.8,129.7,129.1$, $128.7,128.1,127.0,125.2,120.9,105.4,80.7,60.4,25.3,24.7$ (one carbon hidden).

HRMS (ESI $\left.{ }^{+}\right): m / z[M+N a]^{+}$calcd for $\mathrm{C}_{18} \mathrm{H}_{19} \mathrm{NO}_{3} \mathrm{Na}$ : 320.1257; found: 320.1250 . 
4-(tert-Butoxy)-2,2-dimethyl-4,9a-dihydrocyclohepta[b][1,4]oxazin-3(2H)-one (4b) and 4-(tert-Butoxy)-2,2-dimethyl-4,4a-dihydrocyclohepta[b][1,4]oxazin-3(2H)-one $\left(4^{\prime} \mathbf{b}\right)$

Following the general procedure, starting from tropone $(\mathbf{1} ; 30 \mathrm{mg}$, $0.283 \mathrm{mmol}, 1$ equiv), 2-bromo- $\mathrm{N}$-(tert-butoxy)-2-methylpropanamide (2b; $134 \mathrm{mg}, 0.566 \mathrm{mmol}, 2$ equiv), and $\mathrm{Et}_{3} \mathrm{~N}$ (98 $\mu \mathrm{L}, 0.707$ $\mathrm{mmol}, 2.5$ equiv) in HFIP $(1.4 \mathrm{~mL})$ for $16 \mathrm{~h}$, the crude product was purified by flash column chromatography (100/0 to 95/5 pentane/EtOAc) to afford products $\mathbf{4 b}$ as a white solid (53 $\mathrm{mg}, 72 \%$ ) and $\mathbf{4}^{\mathbf{}} \mathbf{b}$ as a white solid (6 mg, $8 \%$ ).

\section{4b}

Mp $55-57^{\circ} \mathrm{C}$.

IR (ATR): 2979, 2935, 1715, 1612, 1523, 1464, 1380, 1368, 1281, 1221 , $1183,1115,1033,980,863 \mathrm{~cm}^{-1}$.

${ }^{1} \mathrm{H} \mathrm{NMR}\left(\mathrm{CDCl}_{3}, 360 \mathrm{MHz}\right): \delta=6.53(\mathrm{ddd}, J=16.7,11.0,6.2 \mathrm{~Hz}, 2 \mathrm{H})$, 6.19 (ddd, $J=9.5,5.7,1.5 \mathrm{~Hz}, 1 \mathrm{H}), 6.01(\mathrm{~d}, J=6.7 \mathrm{~Hz}, 1 \mathrm{H}), 5.32(\mathrm{dt}, J=$ 9.1, 4.6 Hz, $1 \mathrm{H}), 3.83-3.78(\mathrm{~m}, 1 \mathrm{H}), 1.59(\mathrm{~s}, 3 \mathrm{H}), 1.37$ (s, $3 \mathrm{H}), 1.19$ (s, $J=3.8 \mathrm{~Hz}, 9 \mathrm{H})$.

${ }^{13} \mathrm{C} \mathrm{NMR}\left(\mathrm{CDCl}_{3}, 91 \mathrm{MHz}\right): \delta=173.1,132.5,129.1,126.8,124.1,123.4$, 101.4, 86.3, 78.2, 71.3, 27.4, 25.9, 21.2.

HRMS $\left(\mathrm{ESI}^{+}\right): \mathrm{m} / z[\mathrm{M}+\mathrm{H}]^{+}$calcd for $\mathrm{C}_{15} \mathrm{H}_{22} \mathrm{NO}_{3}$ : 264.1594; found: 264.1588 .

\section{4'b}

Mp 88-90 ${ }^{\circ} \mathrm{C}$.

IR (ATR): 2984, 2840, 1702, 1682, 1578, 1385, 1367, 1284, 1143, 1006 , $964,868 \mathrm{~cm}^{-1}$.

${ }^{1} \mathrm{H} \mathrm{NMR}\left(\mathrm{CDCl}_{3}, 360 \mathrm{MHz}\right): \delta=6.52-6.45(\mathrm{~m}, 2 \mathrm{H}), 6.24-6.18(\mathrm{~m}, 1 \mathrm{H})$, 5.81-5.75 (m, $1 \mathrm{H}), 5.47$ (dd, $J=9.5,4.8 \mathrm{~Hz}, 1 \mathrm{H}), 3.80(\mathrm{~d}, J=4.8 \mathrm{~Hz}, 1$ $\mathrm{H}), 1.62(\mathrm{~s}, 3 \mathrm{H}), 1.48(\mathrm{~s}, 3 \mathrm{H}), 1.29(\mathrm{~s}, 9 \mathrm{H})$.

${ }^{13} \mathrm{C}$ NMR $\left(\mathrm{CDCl}_{3}, 101 \mathrm{MHz}\right): \delta=173.1,141.9,128.6,127.1,125.4$, $122.1,104.5,84.4,81.2,62.4,27.5,26.6,23.6$.

HRMS (ESI $\left.{ }^{+}\right): m / z[\mathrm{M}+\mathrm{Na}]^{+}$calcd for $\mathrm{C}_{15} \mathrm{H}_{21} \mathrm{NO}_{3} \mathrm{Na}$ : 286.1414; found: 286.1409.

\section{4-Methoxy-2,2-dimethyl-4,9a-dihydrocyclohepta[b][1,4] oxazin- $3(2 \mathrm{H})$-one (4c) and 4-Methoxy-2,2-dimethyl-4,4a-dihydrocyclo- hepta[b][1,4]oxazin-3(2H)-one (4'c)}

Following the general procedure, starting from tropone $(\mathbf{1} ; 30 \mathrm{mg}$, $0.283 \mathrm{mmol}, 1$ equiv), 2-bromo- $N$-methoxy-2-methylpropanamide (2c; $111 \mathrm{mg}, 0.566 \mathrm{mmol}, 2$ equiv), and $\mathrm{Et}_{3} \mathrm{~N}$ (98 $\mu \mathrm{L}, 0.707 \mathrm{mmol}, 2.5$ equiv) in HFIP $(1.4 \mathrm{~mL})$ for $3 \mathrm{~h}$, the crude product was purified by flash column chromatography (100/0 to $95 / 5$ pentane/EtOAc) to afford products $\mathbf{4 c}$ as an orange oil (39 $\mathrm{mg}, 63 \%$ ) and 4 'c as an orange oil (5 mg, 8\%).

\section{4c}

IR (ATR): 2987, 2835, 1708 1685, 1436, 1398, 1375, 1284, 1111, 1004, $971,868 \mathrm{~cm}^{-1}$.

${ }^{1} \mathrm{H}$ NMR $\left(\mathrm{CDCl}_{3}, 360 \mathrm{MHz}\right): \delta=6.54(\mathrm{ddd}, J=16.8,11.1,6.3 \mathrm{~Hz}, 2 \mathrm{H})$, 6.21 (ddd, $J=10.0,5.8,1.7 \mathrm{~Hz}, 1 \mathrm{H}$ ), 5.94 (dd, $J=6.8,1.5 \mathrm{~Hz}, 1 \mathrm{H}$ ), 5.26 $(\mathrm{dd}, J=9.8,3.6 \mathrm{~Hz}, 1 \mathrm{H}), 3.88(\mathrm{dt}, J=3.6,1.8 \mathrm{~Hz}, 1 \mathrm{H}), 3.70(\mathrm{~s}, 3 \mathrm{H}), 1.57$ (s, $3 \mathrm{H}), 1.40(\mathrm{~s}, 3 \mathrm{H})$.

${ }^{13} \mathrm{C} \mathrm{NMR}\left(\mathrm{CDCl}_{3}, 91 \mathrm{MHz}\right): \delta=168.2,128.9,128.3,127.3,124.4,123.2$, $100.2,77.3,70.4,61.9,25.0,21.5$.
HRMS $\left(\mathrm{ESI}^{+}\right): \mathrm{m} / z[\mathrm{M}+\mathrm{Na}]^{+}$calcd for $\mathrm{C}_{12} \mathrm{H}_{15} \mathrm{NO}_{3} \mathrm{Na}$ : 244.0944; found: 244.0934 .

4'c

IR (ATR): 2985, 2838, 1702, 1682, 1578, 1503, 1385, 1367, 1150, 1008 , $970 \mathrm{~cm}^{-1}$.

${ }^{1} \mathrm{H} \mathrm{NMR}\left(\mathrm{CDCl}_{3}, 360 \mathrm{MHz}\right): \delta=6.59-6.47(\mathrm{~m}, 2 \mathrm{H}), 6.26(\mathrm{dd}, J=9.5,4.9$ $\mathrm{Hz}, 1 \mathrm{H}), 5.83(\mathrm{~d}, J=5.8 \mathrm{~Hz}, 1 \mathrm{H}), 5.41(\mathrm{dd}, J=9.4,4.7 \mathrm{~Hz}, 1 \mathrm{H}), 3.88(\mathrm{~s}$, $3 \mathrm{H}), 3.70(\mathrm{~d}, J=5.0 \mathrm{~Hz}, 1 \mathrm{H}), 1.56(\mathrm{br} \mathrm{s}, 6 \mathrm{H})$.

${ }^{13} \mathrm{C}$ NMR $\left(\mathrm{CDCl}_{3}, 101 \mathrm{MHz}\right): \delta=169.3,140.2,128.2,127.1,125.4$, 120.9, 105.6, 80.7, 62.4, 59.4, 25.2, 24.7.

HRMS $\left(\mathrm{ESI}^{+}\right): \mathrm{m} / z[\mathrm{M}+\mathrm{Na}]^{+}$calcd for $\mathrm{C}_{12} \mathrm{H}_{15} \mathrm{NO}_{3} \mathrm{Na}$ : 244.0944; found: 244.0939 .

4-(Allyloxy)-2,2-dimethyl-4,9a-dihydrocyclohepta[b][1,4]oxazin3(2H)-one (4d)

Following the general procedure, starting from tropone $(\mathbf{1} ; 50 \mathrm{mg}$, $0.471 \mathrm{mmol}, 1$ equiv), $\mathrm{N}$-(allyloxy)-2-bromo-2-methylpropanamide (2d; $209 \mathrm{mg}, 0.942 \mathrm{mmol}, 2$ equiv), and $\mathrm{Et}_{3} \mathrm{~N}$ (164 $\mu \mathrm{L}, 1.180 \mathrm{mmol}, 2.5$ equiv) in HFIP $(2.3 \mathrm{~mL})$ for $16 \mathrm{~h}$, the crude product was purified by flash column chromatography (100/0 to $95 / 5$ pentane/EtOAc) to afford product 4d as an orange oil ( $87 \mathrm{mg}, 75 \%$ ).

Scale-up: Starting from tropone (1; $606 \mathrm{mg}, 5.7 \mathrm{mmol}, 1$ equiv), 2d (2.52 g, $11.43 \mathrm{mmol}, 2$ equiv), and $\mathrm{Et}_{3} \mathrm{~N}$ ( $2 \mathrm{~mL}, 14.27 \mathrm{mmol}, 2.5$ equiv) in HFIP ( $28 \mathrm{~mL}$ ) for $16 \mathrm{~h}$, the crude product was purified by flash column chromatography (100/0 to $95 / 5$ pentane/EtOAc) to afford product $4 d$ as an orange oil (1.08 g, 77\%).

IR (ATR): 2984, 2939, 1872, 1714, 1682, 1613, 1526, 1504, 1382, 1304, $1227,1172,1112,1031,984,844 \mathrm{~cm}^{-1}$.

${ }^{1} \mathrm{H} \mathrm{NMR}\left(\mathrm{CDCl}_{3}, 360 \mathrm{MHz}\right): \delta=6.59(\mathrm{dd}, J=11.1,6.8 \mathrm{~Hz}, 1 \mathrm{H}), 6.48(\mathrm{dd}$, $J=11.1,5.7 \mathrm{~Hz}, 1 \mathrm{H}), 6.19(\mathrm{ddd}, J=9.7,5.7,1.5 \mathrm{~Hz}, 1 \mathrm{H}), 5.99-5.83(\mathrm{~m}$, $2 \mathrm{H}), 5.30-5.19(\mathrm{~m}, 3 \mathrm{H}), 4.38-4.28(\mathrm{~m}, 2 \mathrm{H}), 3.85$ (dt, J = 3.5, $1.7 \mathrm{~Hz}, 1$ $\mathrm{H}), 1.55$ (s, $3 \mathrm{H}), 1.39$ (s, $3 \mathrm{H})$.

${ }^{13} \mathrm{C} \mathrm{NMR}\left(\mathrm{CDCl}_{3}, 91 \mathrm{MHz}\right): \delta=168.8,131.1,128.9,128.8,127.1,124.1$, 123.3, 121.4, 100.4, 77.3, 75.1, 70.5, 25.0, 21.3.

HRMS $\left(\mathrm{ESI}^{+}\right): \mathrm{m} / z[\mathrm{M}+\mathrm{Na}]^{+}$calcd for $\mathrm{C}_{14} \mathrm{H}_{17} \mathrm{NO}_{3} \mathrm{Na}$ : 270.1101; found: 270.1094

\section{2,2-Dimethyl-4-phenoxy-4,4a-dihydrocyclohepta[b][1,4]oxazin- $3(2 \mathrm{H})$-one (4'e)}

Following the general procedure, starting from tropone $(\mathbf{1} ; 30 \mathrm{mg}$, $0.283 \mathrm{mmol}, 1$ equiv), 2-bromo-2-methyl- $\mathrm{N}$-phenoxypropanamide (2e; $146 \mathrm{mg}, 0.566 \mathrm{mmol}, 2$ equiv), and $\mathrm{Et}_{3} \mathrm{~N}$ ( $98 \mu \mathrm{L}, 0.707 \mathrm{mmol}, 2.5$ equiv) in HFIP $(1.4 \mathrm{~mL})$ for $16 \mathrm{~h}$, the crude product was purified by flash column chromatography (100/0 to $95 / 5$ pentane/EtOAc) to afford product 4'e as an orange oil (38 $\mathrm{mg}, 47 \%$ ).

IR (ATR): 2980, 2835, 1754, 1709, 1591, 1542, 1488, 1381, 1291, 1198 , $1168,1000,962,872 \mathrm{~cm}^{-1}$.

${ }^{1} \mathrm{H} \mathrm{NMR}\left(\mathrm{CDCl}_{3}, 360 \mathrm{MHz}\right): \delta=7.36-7.30(\mathrm{~m}, 2 \mathrm{H}), 7.12-7.02(\mathrm{~m}, 3 \mathrm{H})$, 6.54-6.46 (m, $2 \mathrm{H}), 6.20$ (ddd, $J=9.3,3.6,1.6 \mathrm{~Hz}, 1 \mathrm{H}), 5.90$ (d, $J=5.4$ $\mathrm{Hz}, 1 \mathrm{H}), 5.43(\mathrm{dd}, J=9.5,4.7 \mathrm{~Hz}, 1 \mathrm{H}), 3.86(\mathrm{~d}, J=4.7 \mathrm{~Hz}, 1 \mathrm{H}), 1.56(\mathrm{br}$ s, $6 \mathrm{H})$.

${ }^{13} \mathrm{C} \mathrm{NMR}\left(\mathrm{CDCl}_{3}, 91 \mathrm{MHz}\right): \delta=170.5,158.3,139.9,129.8,128.1,127.4$, 125.5, 123.6, 120.3, 113.6, 106.1, 81.3, 60.9, 25.2, 24.9.

HRMS $\left(\right.$ ESI $\left.^{+}\right): m / z[M+H]^{+}$calcd for $\mathrm{C}_{17} \mathrm{H}_{18} \mathrm{NO}_{3}: 284.1281$; found: 284.1276. 
4-(Benzyloxy)-4,9a-dihydro-3H-spiro[cyclohepta[b][1,4] oxazine2,1'-cyclohexan]-3-one (4f), 4-(Benzyloxy)-4,4a-dihydro-3Hspiro[cyclohepta[b][1,4]oxazine-2,1'-cyclohexan]-3-one (4'f), and 15-(Benzyloxy)-7-oxa-15-azadispiro[5.1.6 $\left.{ }^{8} .2^{6}\right]$ hexadeca-9,11,13trien-16-one (3f)

Following the general procedure, starting from tropone $(\mathbf{1} ; 30 \mathrm{mg}$, $0.283 \mathrm{mmol}, 1$ equiv), $N$-(benzyloxy)-1-bromocyclohexanecarboxamide (2f; $176 \mathrm{mg}, 0.566 \mathrm{mmol}$, 2 equiv), and $\mathrm{Et}_{3} \mathrm{~N}(98 \mu \mathrm{L}, 0.707 \mathrm{mmol}$, 2.5 equiv) in HFIP $(1.4 \mathrm{~mL})$ for $36 \mathrm{~h}$, the crude product was purified by flash column chromatography (100/0 to $95 / 5$ pentane/EtOAc) to afford products $4 \mathbf{f}$ as an orange oil ( $40 \mathrm{mg}, 42 \%), \mathbf{4}$ 'f as an orange oil (42 $\mathrm{mg}, 45 \%)$, and $\mathbf{3 f}$ as an orange oil ( $5 \mathrm{mg}, 5 \%$ ).

\section{4f}

IR (ATR): 2933, 2858, 1698, 1611, 1502, 1451, 1272, 1102, 1032, 970 , $844 \mathrm{~cm}^{-1}$.

${ }^{1} \mathrm{H} \mathrm{NMR}\left(\mathrm{CDCl}_{3}, 300 \mathrm{MHz}\right): \delta=7.42-7.28(\mathrm{~m}, 5 \mathrm{H}), 6.59(\mathrm{dd}, J=11.0$, $6.8 \mathrm{~Hz}, 1 \mathrm{H}$ ), 6.48 (dd, $J=11.0,5.6 \mathrm{~Hz}, 1 \mathrm{H}$ ), 6.18 (ddd, $J=9.7,5.7,1.5$ $\mathrm{Hz}, 1 \mathrm{H}$ ), 5.98 (dd, $J=6.7,1.2 \mathrm{~Hz}, 1 \mathrm{H}$ ), $5.22(\mathrm{dd}, J=9.7,3.7 \mathrm{~Hz}, 1 \mathrm{H}$ ), $4.91(\mathrm{~d}, J=9.7 \mathrm{~Hz}, 1 \mathrm{H}), 4.79(\mathrm{~d}, J=9.7 \mathrm{~Hz}, 1 \mathrm{H}), 3.79(\mathrm{dt}, J=3.3,1.6 \mathrm{~Hz}$, $1 \mathrm{H}), 2.20-2.04$ (m, $1 \mathrm{H}), 1.99-1.91$ ( $\mathrm{m}, 1 \mathrm{H}), 1.87-1.26$ (m, $8 \mathrm{H})$.

${ }^{13} \mathrm{C} \mathrm{NMR}\left(\mathrm{CDCl}_{3}, 91 \mathrm{MHz}\right): \delta=169.0,134.0,129.9,129.1,129.0,128.9$, $128.5,127.0,124.1,123.3,100.4,78.4,76.4,69.8,32.4,28.8,25.2$, 21.0, 20.9.

HRMS $\left(\right.$ ESI $\left.^{+}\right): m / z[M+H]^{+}$calcd for $\mathrm{C}_{21} \mathrm{H}_{24} \mathrm{NO}_{3}$ : 338.1751; found: 338.1740 .

\section{4'f}

IR (ATR): 2934, 2858, 1683, 1611, 1502, 1449, 1378, 1273, 1241, 1112, $1032,970,914 \mathrm{~cm}^{-1}$.

${ }^{1} \mathrm{H} \mathrm{NMR}\left(\mathrm{CDCl}_{3}, 300 \mathrm{MHz}\right): \delta=7.47-7.41(\mathrm{~m}, 2 \mathrm{H}), 7.38-7.32(\mathrm{~m}, 3 \mathrm{H})$, 6.58-6.41 (m, $2 \mathrm{H}), 6.26-6.16(\mathrm{~m}, 1 \mathrm{H}), 5.84(\mathrm{~d}, J=5.7 \mathrm{~Hz}, 1 \mathrm{H}), 5.36$ (dd, $J=9.5,4.7 \mathrm{~Hz}, 1 \mathrm{H}), 5.06(\mathrm{~s}, J=10.3 \mathrm{~Hz}, 2 \mathrm{H}), 3.50(\mathrm{~d}, J=4.7 \mathrm{~Hz}, 1$ H), 2.13-2.01 (m, $1 \mathrm{H}), 1.99-1.78$ (m, $3 \mathrm{H}), 1.73-1.55$ (m, $5 \mathrm{H}), 1.42-$ $1.24(\mathrm{~m}, 1 \mathrm{H})$.

${ }^{13} \mathrm{C}$ NMR $\left(\mathrm{CDCl}_{3}, 101 \mathrm{MHz}\right): \delta=169.7,139.9,134.8,129.7,129.1$, 128.6, 127.9, 127.0, 125.1, 121.0, 105.6, 81.6, 60.2, 32.3, 31.5, 24.8, 20.6, 20.5 (one carbon hidden).

HRMS (ESI $\left.{ }^{+}\right): m / z[\mathrm{M}+\mathrm{Na}]^{+}$calcd for $\mathrm{C}_{21} \mathrm{H}_{23} \mathrm{NO}_{3} \mathrm{Na}$ : 360.1570 ; found: 360.1556 .

\section{3f}

Product unstable on silica gel.

IR (ATR): 2938, 2860, 1702, 1562, 1398, 1358, 1289, 1241, 1110, 1035 , $981,914 \mathrm{~cm}^{-1}$.

${ }^{1} \mathrm{H} \mathrm{NMR}\left(\mathrm{CDCl}_{3}, 300 \mathrm{MHz}\right): \delta=7.43-7.28(\mathrm{~m}, 5 \mathrm{H}), 6.59-6.51(\mathrm{~m}, 2 \mathrm{H})$, 6.50-6.40 (m, $2 \mathrm{H}), 5.66$ (d, $J=10.8 \mathrm{~Hz}, 2 \mathrm{H}), 5.03$ (s, $2 \mathrm{H}), 1.86-1.42$ $(\mathrm{m}, 10 \mathrm{H})$.

${ }^{13} \mathrm{C} \mathrm{NMR}\left(\mathrm{CDCl}_{3}, 91 \mathrm{MHz}\right): \delta=171.4,134.7,130.1,129.8,129.0,128.5$, 128.1, 127.0, 89.6, 78.7, 78.2, 35.2, 24.9, 21.2.

HRMS $\left(\mathrm{ESI}^{+}\right): m / z[\mathrm{M}+\mathrm{Na}]^{+}$calcd for $\mathrm{C}_{21} \mathrm{H}_{23} \mathrm{NO}_{3} \mathrm{Na}$ : 360.1570; found: 360.1561 .

\section{4-(Benzyloxy)-2,2-dichloro-1-oxa-4-azaspiro[4.6]undeca-6,8,10- trien-3-one (3g)}

Following the general procedure, starting from tropone $(\mathbf{1} ; 30 \mathrm{mg}$, $0.283 \mathrm{mmol}, 1$ equiv), $N$-(benzyloxy)-2,2,2-trichloroacetamide (2g; $151 \mathrm{mg}, 0.566 \mathrm{mmol}, 2$ equiv), and $\mathrm{Et}_{3} \mathrm{~N}$ (98 $\mu \mathrm{L}, 0.707 \mathrm{mmol}, 2.5$ equiv) in HFIP ( $1.4 \mathrm{~mL}$ ) for $3 \mathrm{~h}$, the crude product was purified by flash column chromatography (100/0 to $95 / 5$ pentane/EtOAc) to afford product $3 \mathrm{~g}$ as an orange oil ( $46 \mathrm{mg}, 48 \%$ ).

IR (ATR): 2925, 2855, 1641, 1600, 1567, 1453, 1363, 1082, 1041, 1012 , $918,885,747,696 \mathrm{~cm}^{-1}$.

${ }^{1} \mathrm{H} \mathrm{NMR}\left(\mathrm{CDCl}_{3}, 360 \mathrm{MHz}\right): \delta=7.44-7.28(\mathrm{~m}, 5 \mathrm{H}), 6.97-6.87(\mathrm{~m}, 1 \mathrm{H})$, 6.44-6.35 (m, $1 \mathrm{H}), 6.24-6.06(\mathrm{~m}, 4 \mathrm{H}), 5.13(\mathrm{~s}, 2 \mathrm{H})$.

${ }^{13} \mathrm{C}$ NMR $\left(\mathrm{CDCl}_{3}, 101 \mathrm{MHz}\right): \delta=156.4,137.9,134.1,132.8,132.0$, $130.3,129.5,128.4,128.0,127.8,125.8,76.0$ (two carbons hidden).

HRMS $\left(\mathrm{ESI}^{+}\right): \mathrm{m} / z[\mathrm{M}+\mathrm{Na}]^{+}$calcd for $\mathrm{C}_{16} \mathrm{H}_{13} \mathrm{Cl}_{2} \mathrm{NO}_{3} \mathrm{Na}$ : 360.0165; found: 360.3215 .

4-(Benzyloxy)-2-phenyl-4,9a-dihydrocyclohepta[b][1,4]oxazin$3(2 \mathrm{H})$-one (trans-4h) and 4-(Benzyloxy)-2-phenyl-4,9a-dihydrocyclohepta[b][1,4]oxazin-3(2H)-one (cis-4h)

Following the general procedure, starting from tropone $(\mathbf{1} ; 50 \mathrm{mg}$, $0.471 \mathrm{mmol}, 1$ equiv), $\mathrm{N}$-(benzyloxy)-2-bromo-2-phenylacetamide (2h; $300 \mathrm{mg}, 0.942 \mathrm{mmol}, 2$ equiv), and $\mathrm{Et}_{3} \mathrm{~N}$ ( $164 \mu \mathrm{L}, 1.178 \mathrm{mmol}, 2.5$ equiv) in HFIP ( $2.3 \mathrm{~mL}$ ) for $16 \mathrm{~h}$, the crude product was purified by flash column chromatography (100/0 to $95 / 5$ pentane/EtOAc) to afford the products trans-4h as an orange oil (52 mg, 32\%) and cis-4h as an orange oil (19 $\mathrm{mg}, 12 \%)$.

\section{trans-4h}

IR (ATR): 2938, 2879, 1699, 1611, 1541, 1454, 1116, 1037, $918 \mathrm{~cm}^{-1}$. ${ }^{1} \mathrm{H}$ NMR $\left(\mathrm{CDCl}_{3}, 360 \mathrm{MHz}\right): \delta=7.44-7.33(\mathrm{~m}, 10 \mathrm{H}), 6.62(\mathrm{dd}, J=11.1$, $6.9 \mathrm{~Hz}, 1 \mathrm{H}), 6.52(\mathrm{dd}, J=11.1,5.7 \mathrm{~Hz}, 1 \mathrm{H}), 6.22$ (ddd, $J=9.8,5.7,1.6$ $\mathrm{Hz}, 1 \mathrm{H}), 6.10(\mathrm{dd}, J=7.0,1.6 \mathrm{~Hz}, 1 \mathrm{H}), 5.29(\mathrm{dd}, J=9.9,3.5 \mathrm{~Hz}, 1 \mathrm{H})$, $5.07(\mathrm{~s}, 1 \mathrm{H}), 4.96(\mathrm{~d}, J=9.9 \mathrm{~Hz}, 1 \mathrm{H}), 4.90(\mathrm{~d}, J=9.9 \mathrm{~Hz}, 1 \mathrm{H}), 4.09$ (dt, $J=3.3,1.6 \mathrm{~Hz}, 1 \mathrm{H})$.

${ }^{13} \mathrm{C}$ NMR $\left(\mathrm{CDCl}_{3}, 91 \mathrm{MHz}\right): \delta=165.9,134.6,133.9,130.1,129.1(2 \mathrm{C})$, 129.0, 128.7, 128.5, 128.1, 127.5, 124.4, 122.6, 101.7, 78.9, 76.5, 74.6 (one carbon hidden).

HRMS $\left(\mathrm{ESI}^{+}\right): m / z[\mathrm{M}+\mathrm{H}]^{+}$calcd for $\mathrm{C}_{22} \mathrm{H}_{20} \mathrm{NO}_{3}$ : 346.1438; found: 346.1425 .

\section{cis-4h}

IR (ATR): 2938, 2849, 1699, 1611, 1531, 1454, 1362, 1115, 1076, 996 $\mathrm{cm}^{-1}$.

${ }^{1} \mathrm{H} \mathrm{NMR}\left(\mathrm{CDCl}_{3}, 360 \mathrm{MHz}\right): \delta=7.49-7.41(\mathrm{~m}, 2 \mathrm{H}), 7.38-7.29(\mathrm{~m}, 8 \mathrm{H})$, $6.49(\mathrm{dd}, J=11.1,6.8 \mathrm{~Hz}, 1 \mathrm{H}), 6.40(\mathrm{dd}, J=11.1,5.6 \mathrm{~Hz}, 1 \mathrm{H}), 6.17$ (ddd, $J=9.9,5.6,1.6 \mathrm{~Hz}, 1 \mathrm{H}), 6.00(\mathrm{dd}, J=6.7,1.2 \mathrm{~Hz}, 1 \mathrm{H}), 5.63(\mathrm{~s}, 1$ H), $5.31(\mathrm{dd}, J=9.8,3.8 \mathrm{~Hz}, 1 \mathrm{H}), 5.04(\mathrm{~d}, J=9.6 \mathrm{~Hz}, 1 \mathrm{H}), 4.93(\mathrm{~d}, J=9.6$ $\mathrm{Hz}, 1 \mathrm{H}), 3.70-3.68(\mathrm{~m}, 1 \mathrm{H})$.

${ }^{13} \mathrm{C} \mathrm{NMR}\left(\mathrm{CDCl}_{3}, 91 \mathrm{MHz}\right): \delta=164.2,133.8,133.2,130.0,129.2,129.1$, 129.0, 128.9, 128.6, 128.1, 127.4, 124.5, 122.5, 101.3, 78.7, 76.8, 70.7 (one carbon hidden).

HRMS $\left(\right.$ ESI $\left.^{+}\right): m / z[M+\mathrm{H}]^{+}$calcd for $\mathrm{C}_{22} \mathrm{H}_{20} \mathrm{NO}_{3}$ : 346.1438; found: 346.1427 .

\section{3,3-Dimethyl-4-phenoxy-9-phenyl-4,4a-dihydrocyclohepta- [b][1,4]oxazin-2(3H)-one (6e)}

Following the general procedure, starting from 2-phenylcyclohepta2,4,6-trienone (5; $43 \mathrm{mg}, 0.236 \mathrm{mmol}, 1$ equiv), 2-bromo-2-methyl$\mathrm{N}$-phenoxypropanamide (2e; $121 \mathrm{mg}, 0.472 \mathrm{mmol}, 2$ equiv), and $\mathrm{Et}_{3} \mathrm{~N}$ ( $83 \mu \mathrm{L}, 0.590 \mathrm{mmol}, 2.5$ equiv) in HFIP $(1.2 \mathrm{~mL})$ for $16 \mathrm{~h}$, the crude 
product was purified by flash column chromatography (100/0 to $95 / 5$ pentane/EtOAc) to afford product $\mathbf{6 e}$ as an orange solid (47 mg, 56\%); $\mathrm{mp} 133-135^{\circ} \mathrm{C}$.

IR (ATR): 2990, 2939, 2875, 1705, 1694, 1591, 1487, 1379, 1362, 1293 , $1170,1154,1000,964 \mathrm{~cm}^{-1}$.

${ }^{1} \mathrm{H}$ NMR $\left(\mathrm{CDCl}_{3}, 360 \mathrm{MHz}\right): \delta=7.41-7.28(\mathrm{~m}, 7 \mathrm{H}), 7.13-7.07(\mathrm{~m}, 3 \mathrm{H})$, 6.74-6.68 (m, $1 \mathrm{H}), 6.62-6.56(\mathrm{~m}, 1 \mathrm{H}), 6.30$ (ddd, $J=9.3,5.3,1.7 \mathrm{~Hz}, 1$ $\mathrm{H}), 5.66(\mathrm{dd}, J=9.3,4.9 \mathrm{~Hz}, 1 \mathrm{H}), 4.07(\mathrm{dd}, J=5.0,1.5 \mathrm{~Hz}, 1 \mathrm{H}), 1.68(\mathrm{~s}$, $3 \mathrm{H}), 1.60(\mathrm{~s}, 3 \mathrm{H})$.

${ }^{13} \mathrm{C} \mathrm{NMR}\left(\mathrm{CDCl}_{3}, 91 \mathrm{MHz}\right): \delta=170.3,158.0,137.1,136.2,132.5,129.9$, $129.4,128.1,127.3,127.0,125.5,123.7,123.2,118.8,113.8,81.6,61.0$, 25.7, 24.6.

HRMS (ESI $\left.{ }^{+}\right): m / z[\mathrm{M}+\mathrm{H}]^{+}$calcd for $\mathrm{C}_{23} \mathrm{H}_{22} \mathrm{NO}_{3}: 360.1594$; found: 360.1577 .

\section{4-(Benzyloxy)-3,3-dimethyl-9-phenyl-4,4a-dihydrocyclohepta- [b][1,4]oxazin-2(3H)-one (6a) and 4-(Benzyloxy)-2,2-dimethyl-5- phenyl-4,9a-dihydrocyclohepta[b][1,4] oxazin-3(2H)-one (6b)}

Following the general procedure, starting from 2-phenylcyclohepta2,4,6-trienone (5; $80 \mathrm{mg}, 0.425 \mathrm{mmol}, 1$ equiv), $N$-(benzyloxy)-2-bromo-2-methylpropanamide (2a; $231 \mathrm{mg}, 0.850 \mathrm{mmol}, 2$ equiv), and $\mathrm{Et}_{3} \mathrm{~N}(148 \mu \mathrm{L}, 1.060 \mathrm{mmol}, 2.5$ equiv) in $\operatorname{HFIP}(2.1 \mathrm{~mL})$ for $16 \mathrm{~h}$, the crude product was purified by flash column chromatography (100/0 to $95 / 5$ pentane/EtOAc) to afford product $\mathbf{6 a}$ as an orange oil ( $89 \mathrm{mg}$, $56 \%$ and $\mathbf{6 b}$ as an orange solid (19 $\mathrm{mg}, 12 \%)$.

\section{6a}

IR (ATR): 2988, 2835, 1687, 1653, 1603, 1455, 1376, 1295, 1150, 1029, $1014,908 \mathrm{~cm}^{-1}$.

${ }^{1} \mathrm{H} \mathrm{NMR}\left(\mathrm{CDCl}_{3}, 360 \mathrm{MHz}\right): \delta=7.50-7.42(\mathrm{~m}, 2 \mathrm{H}), 7.40-7.25(\mathrm{~m}, 8 \mathrm{H})$, 6.66-6.53 (m, $2 \mathrm{H}$ ), 6.27 (ddd, $J=9.2,5.0,1.4 \mathrm{~Hz}, 1 \mathrm{H}), 5.52$ (dd, $J=9.3$, $5.1 \mathrm{~Hz}, 1 \mathrm{H}), 5.16-5.04(\mathrm{~m}, 2 \mathrm{H}), 3.74(\mathrm{dd}, J=5.1,1.5 \mathrm{~Hz}, 1 \mathrm{H}), 1.56(\mathrm{~s}, 3$ $\mathrm{H}), 1.50(\mathrm{~s}, 3 \mathrm{H})$.

${ }^{13} \mathrm{C} \mathrm{NMR}\left(\mathrm{CDCl}_{3}, 91 \mathrm{MHz}\right): \delta=169.3,137.3,136.4,134.8,132.4,130.5$, 129.7, 129.5, 129.1, 128.7, 128.1, 127.1, 126.9, 125.2, 123.8, 117.9, 81.0, 60.6, 25.8, 24.5.

HRMS $\left(\mathrm{ESI}^{+}\right): \mathrm{m} / z[\mathrm{M}+\mathrm{H}]^{+}$calcd for $\mathrm{C}_{24} \mathrm{H}_{24} \mathrm{NO}_{3}$ : 374.1751; found: 374.1732 .

\section{6b}

Mp $110-112^{\circ} \mathrm{C}$.

IR (ATR): 2978, 2936, 2850, 1704, 1595, 1490, 1452, 1382, 1323, 1280 , $1224,1170,1130,988 \mathrm{~cm}^{-1}$.

${ }^{1} \mathrm{H} \mathrm{NMR}\left(\mathrm{CDCl}_{3}, 360 \mathrm{MHz}\right): \delta=7.37-7.31(\mathrm{~m}, 2 \mathrm{H}), 7.28-7.23(\mathrm{~m}, 3 \mathrm{H})$, 7.21-7.10 (m, 3 H), 6.86-6.78 (m, $2 \mathrm{H}), 6.77-6.74(\mathrm{~m}, 1 \mathrm{H}), 6.70-6.62$ $(\mathrm{m}, 1 \mathrm{H}), 6.28$ (ddd, $J=9.2,5.5,1.7 \mathrm{~Hz}, 1 \mathrm{H}), 5.27(\mathrm{dd}, J=9.3,4.4 \mathrm{~Hz}, 1$ H), $4.42(\mathrm{~s}, 2 \mathrm{H}), 3.58(\mathrm{dd}, J=4.3,1.7 \mathrm{~Hz}, 1 \mathrm{H}), 1.62(\mathrm{~s}, 3 \mathrm{H}), 1.59(\mathrm{~s}, 3$ $\mathrm{H})$.

${ }^{13} \mathrm{C}$ NMR $\left(\mathrm{CDCl}_{3}, 101 \mathrm{MHz}\right): \delta=168.7,139.1,134.0,133.0,129.6$, 129.5, 129.1, 128.5, 128.1, 128.1, 127.4, 126.1, 123.7, 120.7, 117.0, 77.7, 75.0, 72.7, 24.9, 21.1.

HRMS $\left(\mathrm{ESI}^{+}\right): \mathrm{m} / z[\mathrm{M}+\mathrm{H}]^{+}$calcd for $\mathrm{C}_{24} \mathrm{H}_{24} \mathrm{NO}_{3}$ : 374.1751; found: 374.1743.
2,2-Dimethyl-4,9a-dihydrocyclohepta[b][1,4]oxazin-3(2H)-one (7) In a round-bottomed flask, were placed compound $\mathbf{4 a}(100 \mathrm{mg}, 0.337$ mmol, 1 equiv) and $\left[\mathrm{Mo}(\mathrm{CO})_{6}\right]$ ( $195 \mathrm{mg}, 0.740 \mathrm{mmol}, 2.2$ equiv). A mixture $\mathrm{MeCN} / \mathrm{H}_{2} \mathrm{O}(9: 1,3 \mathrm{~mL})$ was added and the reaction mixture was stirred under reflux for $16 \mathrm{~h}$. Then, it was filtered through a short pad of Celite, which was rinsed with $\mathrm{CH}_{2} \mathrm{Cl}_{2}$. The solution was dried (anhyd $\mathrm{MgSO}_{4}$ ), filtered, and the solvent was removed with rotary evaporation. The crude product was purified by flash column chromatography (60/40 pentane/EtOAc) to afford product 7 as an orange solid (57 mg, 89\%); mp $161-163{ }^{\circ} \mathrm{C}$.

IR (ATR): 2934, 2874, 1680, 1631, 1531, 1381, 1263, 1226, 1106, 966 $\mathrm{cm}^{-1}$.

${ }^{1} \mathrm{H}$ NMR $\left(\mathrm{CDCl}_{3}, 360 \mathrm{MHz}\right): \delta=8.69($ br s, $1 \mathrm{H}), 6.55-6.41(\mathrm{~m}, 2 \mathrm{H})$, 6.22-6.13 (m, $1 \mathrm{H}), 5.64$ (dd, $J=5.6,1.4 \mathrm{~Hz}, 1 \mathrm{H}), 5.25$ (dd, $J=9.9,3.5$ $\mathrm{Hz}, 1 \mathrm{H}), 3.88$ (dt, J = 3.5, $1.8 \mathrm{~Hz}, 1 \mathrm{H}), 1.55(\mathrm{~s}, 3 \mathrm{H}), 1.44(\mathrm{~s}, 3 \mathrm{H})$.

${ }^{13} \mathrm{C} \mathrm{NMR}\left(\mathrm{CDCl}_{3}, 91 \mathrm{MHz}\right): \delta=174.5,128.9,128.4,127.2,124.0,123.3$, 101.9, 75.8, 69.1, 24.5, 21.6.

HRMS $\left(\mathrm{ESI}^{+}\right): m / z[\mathrm{M}+\mathrm{Na}]^{+}$calcd for $\mathrm{C}_{11} \mathrm{H}_{13} \mathrm{NO}_{2} \mathrm{Na}$ : 214.0835; found: 214.0828 .

\section{4-(tert-Butoxy)-2,2-dimethyl-4,6,7,8,9,9a-hexahydrocyclohepta-} [b][1,4]oxazin-3(2H)-one (8)

In a round-bottomed flask were placed compound $\mathbf{4 b}$ ( $25 \mathrm{mg}, 0.095$ mmol, 1 equiv) and $\mathrm{Pd} / \mathrm{C}(3 \mathrm{mg}, 10 \% \mathrm{w} / \mathrm{w})$. EtOAc $(5 \mathrm{~mL})$ was added and the reaction mixture was stirred at rt for $3 \mathrm{~h}$ under $\mathrm{H}_{2}$ atmosphere. Then, it was filtered through a short pad of Celite, which was rinsed with EtOAc. The solvent was removed with rotary evaporation. The crude product was purified by flash column chromatography (90/10 pentane/EtOAc) to afford product 8 as an orange oil (21 mg, $84 \%)$.

IR (ATR): 2929, 2919, 2876, 1699, 1652, 1541, 1472, 1095, $960 \mathrm{~cm}^{-1}$.

${ }^{1} \mathrm{H} \mathrm{NMR}\left(\mathrm{CDCl}_{3}, 360 \mathrm{MHz}\right): \delta=5.60(\mathrm{ddd}, J=9.4,5.8,2.0 \mathrm{~Hz}, 1 \mathrm{H}), 4.61$ $(\mathrm{d}, J=9.9 \mathrm{~Hz}, 1 \mathrm{H}), 2.33-2.22(\mathrm{~m}, 1 \mathrm{H}), 2.08-1.92(\mathrm{~m}, 2 \mathrm{H}), 1.74-1.59$ (m, $5 \mathrm{H}), 1.48(\mathrm{~s}, 3 \mathrm{H}), 1.36(\mathrm{~s}, 3 \mathrm{H}), 1.32(\mathrm{~s}, 9 \mathrm{H})$.

${ }^{13} \mathrm{C} \mathrm{NMR}\left(\mathrm{CDCl}_{3}, 91 \mathrm{MHz}\right): \delta=169.3,138.2,122.6,85.5,78.7,31.9$, 31.3, 30.2, 28.0, 27.2, 26.4, 24.6, 24.2.

HRMS $\left(\mathrm{ESI}^{+}\right): m / z[(\mathrm{M}-\mathrm{BBOH})+\mathrm{Na}]^{+}$calcd for $\mathrm{C}_{11} \mathrm{H}_{16} \mathrm{NO}_{2} \mathrm{Na}$ : 217.1079; found: 217.1069 .

\section{Funding Information}

We gratefully thank the Agence Nationale de la Recherche (ANR-16CE07-0022 funding for G.F.).

\section{Acknowledgment}

We gratefully thank the CNRS and the Université Paris-Sud, Université Paris-Saclay, for their support of this work.

\section{Supporting Information}

Supporting information for this article is available online at https://doi.org/10.1055/s-0039-1690745. 


\section{References}

(1) For relevant reviews on tropone and related compounds, see: (a) Bentley, R. Nat. Prod. Rep. 2008, 25, 118. (b) Liu, N.; Song, W.; Schienebeck, C. M.; Zhang, M.; Tang, W. Tetrahedron 2014, 70, 9281. (c) Dastan, A.; Kilic, H.; Saracoglu, N. Beilstein J. Org. Chem. 2018, 14, 1120. (d) Guo, H.; Roman, D.; Beemelmanns, C. Nat. Prod. Rep. 2019, 36, 1137.

(2) For recent examples of cycloadditions involving tropone derivatives, see: (a) Nair, V.; Poonoth, M.; Vellalath, S.; Suresh, E.; Thirumalai, R. J. Org. Chem. 2006, 71, 8964. (b) Trost, B. M.; McDougall, P. J.; Hartmann, O.; Wathen, P. T. J. Am. Chem. Soc. 2008, 130, 14960. (c) Li, P.; Yamamoto, H. J. Am. Chem. Soc. 2009, 131, 16628. (d) Ashenhurst, J. A.; Isakovic, L.; Gleason, J. L. Tetrahedron 2010, 66, 368. (e) Rivero, A. R.; Fernández, I.; Sierra, M. A. Org. Lett. 2013, 15, 4928. (f) Tejero, R.; Ponce, A.; Adrio, J.; Carretero, J. C. Chem. Commun. 2013, 49, 10406. (g) Liu, H. L.; Wu, Y.; Zhao, Y.; Li, Z.; Zhang, L.; Yang, W. J.; Jiang, H.; Jing, C. F.; Yu, H.; Wang, B.; Xiao, Y. M.; Guo, H. C. J. Am. Chem. Soc. 2014, 136, 2625. (h) Teng, H.-L.; Yao, L.; Wang, C.-J. J. Am. Chem. Soc. 2014, 136, 4075. (i) Kumar, P.; Thakur, A.; Hong, X.; Houk, K. N.; Louie, J. J. Am. Chem. Soc. 2014, 136, 17844. (j) Esteban, F.; Alfaro, R.; Yuste, F.; Parra, A.; Ruano, J. L.; Alemán, J. Eur. J. Org. Chem. 2014, 1395. (k) Thangaraj, M.; Bhojgude, S. S.; Bisht, R. H.; Gonnade, R. G.; Biju, A. T. J. Org. Chem. 2014, 79, 4757. (1) Jia, S.; Su, S.; Li, C.; Jia, X.; Li, J. Org. Lett. 2014, 16, 5604. (m) Mose, R.; Preegel, G.; Larsen, J.; Jakobsen, S.; Iversen, E. H.; Jørgensen, K. A. Nat. Chem. 2017, 9, 487. (n) Yu, P.; Chen, T. Q.; Yang, Z.; He, C. Q.; Patel, A.; Lam, Y.-h.; Liu, C.-Y.; Houk, K. N. J. Am. Chem. Soc. 2017, 139, 8251. (o) Liu, H.; Jia, H.; Shi, W.; Wang, C.; Zhang, C.; Guo, H. Org. Lett. 2018, 20, 3570. (p) Zhang, J.; Xiao, W.; Hu, H.; Lin, L.; Liu, X.; Feng, X. Chem. Eur. J. 2018, 24, 13428. (q) Yu, P.; He, C. Q.; Simon, A.; Li, W.; Mose, R.; Thøgersen, M. K.; Jørgensen, K. A.; Houk, K. N. J. Am. Chem. Soc. 2018, 140, 13726. (r) Xia, F.; Gao, Z.-H.; Zhangm, C.-L.; Ye, S. Adv. Synth. Catal. 2019, 361, 2291. (s) Wang, S.; Rodríguez-Escrich, C.; Fianchini, M.; Maseras, F.; Pericàs, M. A. Org. Lett. 2019, 21, 3187.
(3) For reviews on azaoxyallyl cations, see: (a) Barnes, K. L.; Koster, A. K.; Jeffrey, C. S. Tetrahedron Lett. 2014, 55, 4690. (b) Xuan, J.; Cao, X.; Cheng, X. Chem. Commun. 2018, 54, 5154.

(4) For seminal works, see: (a) Jeffrey, C. S.; Barnes, K. L.; Eickhoff, J. A.; Carson, C. R. J. Am. Chem. Soc. 2011, 133, 7688. (b) DiPoto, M. C.; Hughes, R. P.; Wu, J. J. Am. Chem. Soc. 2015, 137, 14861. For selected recent examples on the use of azaoxyallyl cations in synthesis, see: (c) Zhang, K.; Yang, C.; Yao, H.; Lin, A. Org. Lett. 2016, 18, 4618. (d) Acharya, A.; Montes, K.; Jeffrey, C. S. Org. Lett. 2016, 18, 6082. (e) Shao, P.-L.; Li, Z.-R.; Wang, Z.-P.; Zhou, M.-H.; Wu, Q.; Hu, P.; He, Y. J. Org. Chem. 2017, 82, 10680. (f) DiPoto, M. C.; Wu, J. Org. Lett. 2018, 20, 499. (g) Zhang, C.; Ji, W.; Liu, Y. A.; Song, C.; Liao, X. J. Nat. Prod. 2018, 81, 1065. (h) Xu, X.; Zhang, K.; Li, P.; Yao, H.; Lin, A. Org. Lett. 2018, 20 , 1781. (i) Ji, D.; Sun, J. Org. Lett. 2018, 20, 2745. (j) Singh, R.; Nagesh, K.; Yugandhar, D.; Prasanthi, A. V. G. Org. Lett. 2018, 20 , 4848. (k) Baldé, B.; Force, G.; Marin, L.; Guillot, R.; Schulz, E.; Gandon, V.; Lebœuf, D. Org. Lett. 2018, 20, 7405. (1) Jaiswal, V.; Mondal, B.; Singh, K.; Das, D.; Saha, J. Org. Lett. 2019, 21, 5848.

(5) For recent reviews on HFIP, see: (a) Sugiishi, T.; Matsugi, M.; Hamamoto, H.; Amii, H. RSC Adv. 2015, 5, 17269. (b) WencelDelord, J.; Colobert, F. Org. Chem. Front. 2016, 3, 394. (c) Colomer, I.; Chamberlain, A. E. R.; Haughey, M. B.; Donohoe, T. J. Nat. Rev. Chem. 2017, 1, 0088.

(6) Zhao, Y.; Truhlar, D. G. J. Chem. Phys. 2006, 125, 194101.

(7) (a) MacLean, A. D.; Chandler, G. S. J. Chem. Phys. 1980, 72, 5639. (b) Krishnan, R.; Binkley, J. S.; Seeger, R.; Pople, J. A. J. Chem. Phys. 1980, 72, 650.

(8) Marenich, A. V.; Cramer, C. J.; Truhlar, D. G. J. Phys. Chem. B 2009, 113, 6378.

(9) Li, G.-X.; Morales-Rivera, C. A.; Gao, F.; Wang, Y.; He, G.; Liu, P.; Chen, G. Chem. Sci. 2017, 8, 7180.

(10) When isolated, minor compound 4'a was subjected to the reaction conditions; only $30 \%$ conversion into 4 a was observed after $24 \mathrm{~h}$.

(11) (a) Berkessel, A.; Adrio, J. A.; Hüttenhain, D.; Neudörfl, J. M. J. Am. Chem. Soc. 2006, 128, 8421. (b) Berkessel, A.; Adrio, J. A. J. Am. Chem. Soc. 2006, 128, 13412. 